University of South Florida

DIGITAL COMMONS

Digital Commons @ University of

@ UNIVERSITY OF SOUTH FLORIDA

South Florida

$1-1-2012$

\title{
2012 Annual Report USF System
}

USF

Follow this and additional works at: https://digitalcommons.usf.edu/usf_accountability_reports

\section{Scholar Commons Citation}

USF, "2012 Annual Report USF System" (2012). USF Accountability Reports. 28.

https://digitalcommons.usf.edu/usf_accountability_reports/28

This Article is brought to you for free and open access by the USF Archives at Digital Commons @ University of South Florida. It has been accepted for inclusion in USF Accountability Reports by an authorized administrator of Digital Commons @ University of South Florida. For more information, please contact digitalcommons@usf.edu. 


\section{1-12 \\ Annual Accountability Report}

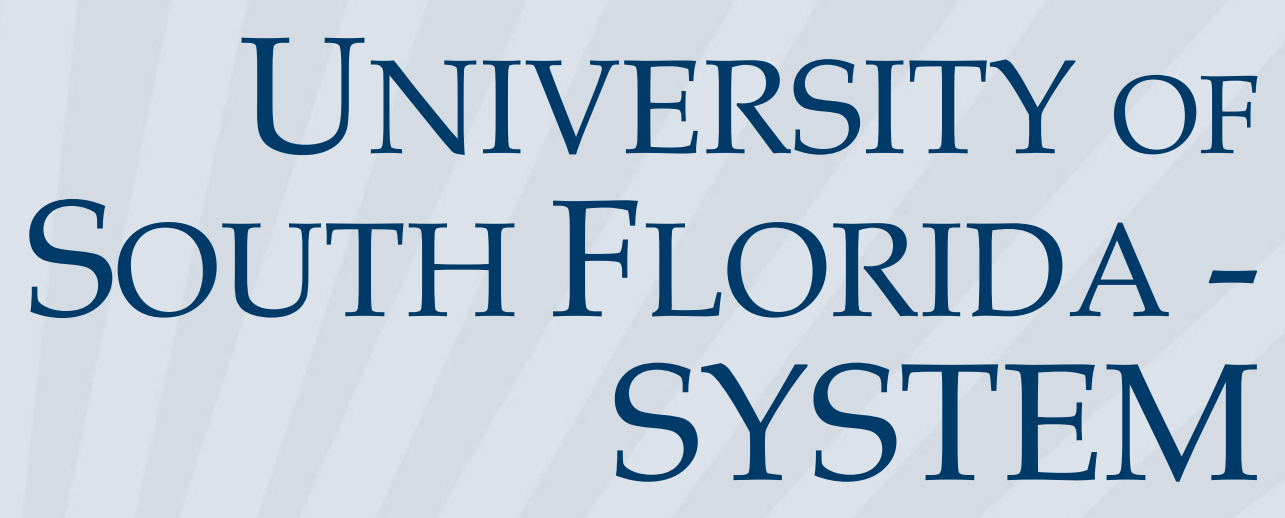

STATE UNIVERSITY SYSTEM of FLORIDA Board of Governors 


\section{$\underline{\text { TABLE OF CONTENTS }}$}

\section{EXECUTIVE SUMMARY}

DASHBOARD

p. 2

KEY ACHIEVEMENTS

p. 5

NARRATIVE

p. 6

\section{DATA TABLES}

SECTION 1. FINANCIAL RESOURCES p. 9

SECTION 2. PERSONNEL p. 13

SECTION 3. ENROLLMENT p. 14

SECTION 4. UNDERGRADUATE EDUCATION p. 18

SECTION 5. GRADUATE EDUCATION p. 28

SECTION 6. RESEARCH \& ECONOMIC DEVELOPMENT p. 31 


\section{Dashboard}

\begin{tabular}{|c|c|c|c|c|c|c|c|}
\hline \multicolumn{3}{|c|}{ Sites and Campuses } & \multicolumn{5}{|c|}{ USF Tampa, USF St. Petersburg, USF Sarasota-Manatee, USF in Lakeland site } \\
\hline \multirow{2}{*}{$\begin{array}{c}\text { Enrollments } \\
\text { TOTAL } \\
\text { (Fall 2011) } \\
\end{array}$} & \multirow{2}{*}{$\begin{array}{c}\text { Headcount } \\
47,362\end{array}$} & \multirow{2}{*}{$\begin{array}{c}\% \\
100 \%\end{array}$} & \multicolumn{3}{|c|}{ Degree Programs Offered (As of Spr. 2012) } & \multicolumn{2}{|c|}{ Carnegie Classification } \\
\hline & & & TOTAL & \multicolumn{2}{|c|}{299} & $\begin{array}{c}\text { Undergraduate } \\
\text { Instructional Program: }\end{array}$ & \multirow{10}{*}{$\begin{array}{l}\text { USF System is not } \\
\text { classified by } \\
\text { Carnegie }\end{array}$} \\
\hline Black & 4,973 & $10 \%$ & Baccalaureate & & & & \\
\hline Hispanic & 7,308 & $15 \%$ & Master's \& Specialist's & & & Program: & \\
\hline White & 28,963 & $61 \%$ & Research Doctorate & & & Enrollment Profile: & \\
\hline Other & 6,118 & $13 \%$ & Professional Doctorate & & & Undergraduate Profile: & \\
\hline Full-Time & 31,815 & $67 \%$ & \multirow{2}{*}{ Faculty (Fall 2011) } & \multirow{2}{*}{$\begin{array}{l}\text { Full- } \\
\text { Time }\end{array}$} & \multirow{2}{*}{$\begin{array}{l}\text { Part- } \\
\text { Time }\end{array}$} & Size and Setting: & \\
\hline Part-Time & 15,547 & $33 \%$ & & & & \multirow{2}{*}{ Basic: } & \\
\hline Undergraduate & 35,764 & $76 \%$ & TOTAL & 1,643 & 449 & & \\
\hline Graduate & 9,433 & $20 \%$ & Tenure/T. Track & 1,142 & 68 & \multirow{2}{*}{$\begin{array}{l}\text { Community } \\
\text { Engagement: }\end{array}$} & \\
\hline Unclassified & 2,165 & $5 \%$ & Non-Ten. Faculty & 501 & 381 & & \\
\hline
\end{tabular}

\section{ACCESS TO AND PRODUCTION OF DEGREES}

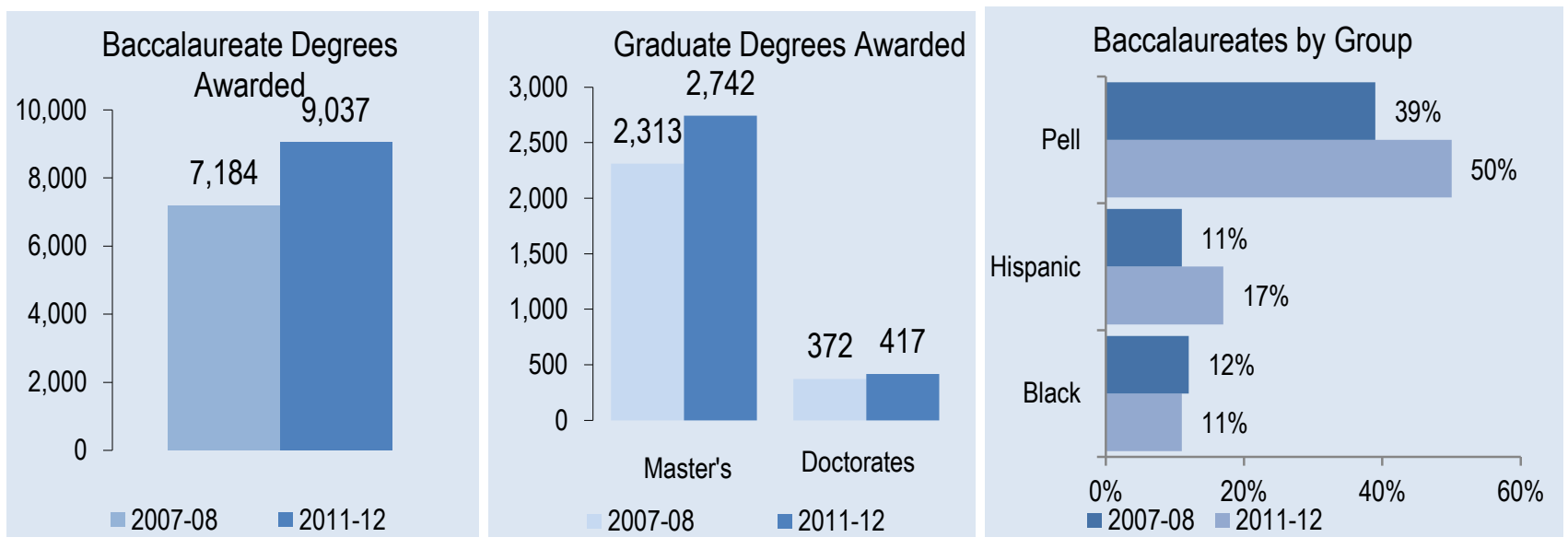

\section{MEETING STATEWIDE PROFESSIONAL AND WORKFORCE NEEDS}

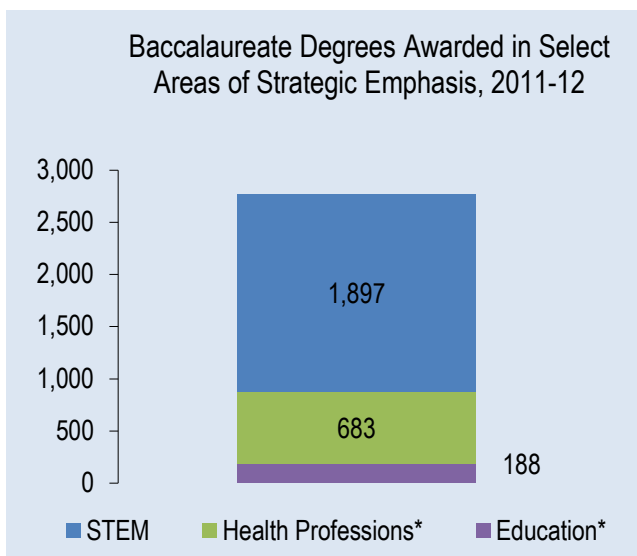

Graduate Degrees Awarded in Select Areas of Strategic Emphasis, 2011-12

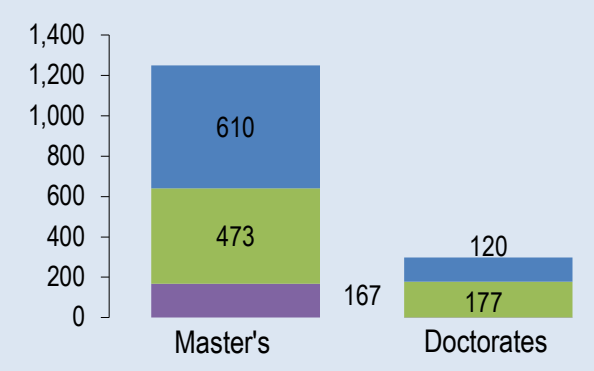

n Education* $\quad$ Health Professions ${ }^{*} \quad$ STEM 


\section{Dashboard}

MEETING STATEWIDE PROFESSIONAL AND WORKFORCE NEEDS

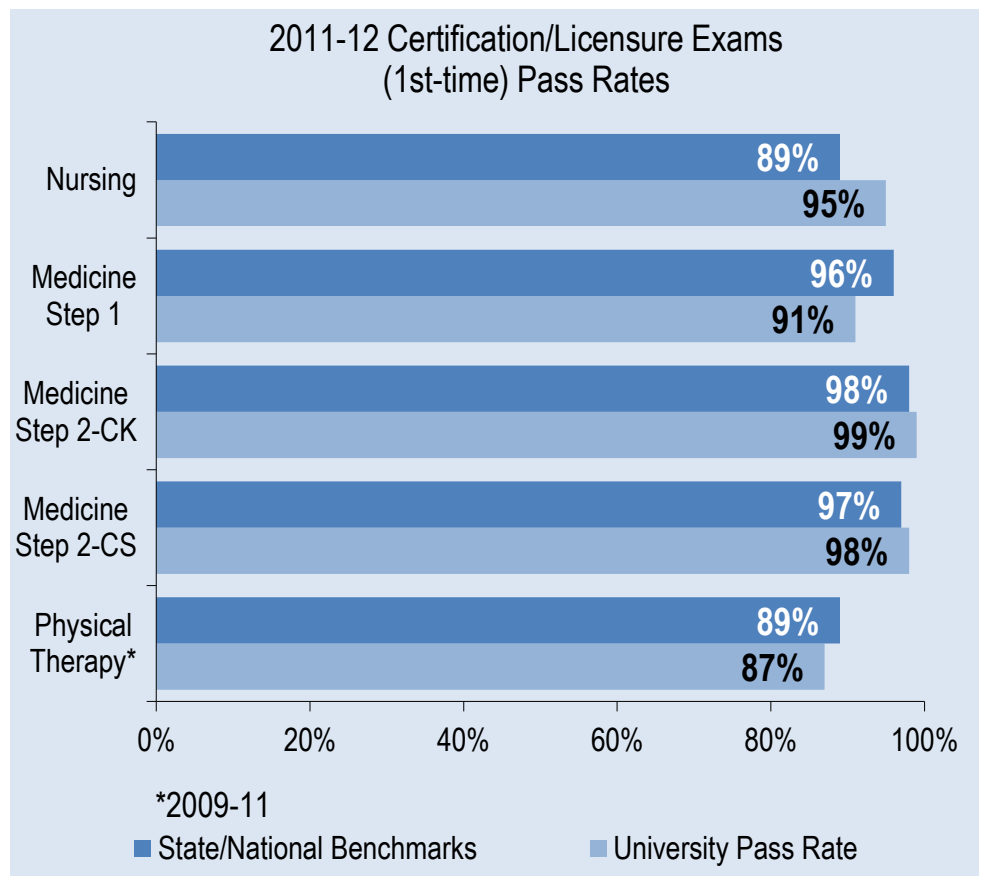

\section{BUILDING WORLD-CLASS ACADEMIC PROGRAMS AND RESEARCH CAPACITY}
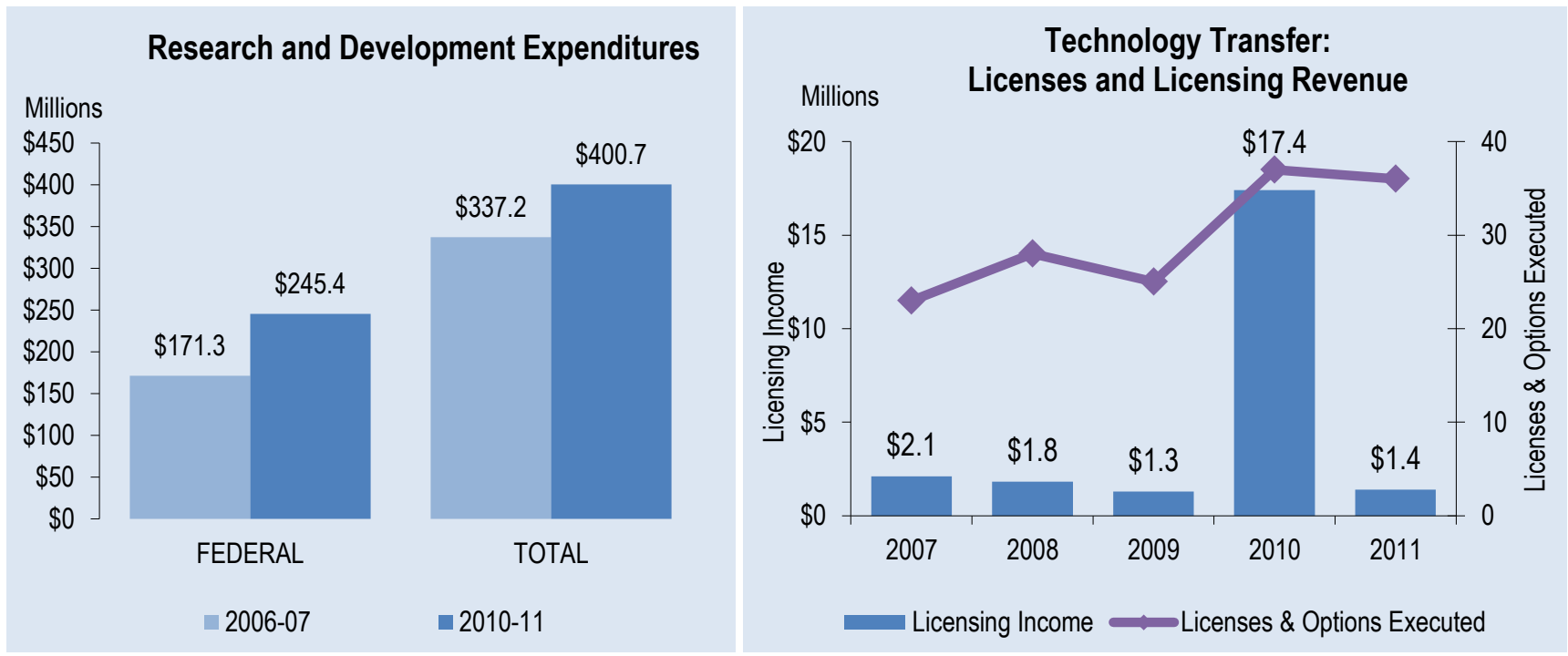


\section{Dashboard}

\section{RESOURCES, EFFICIENCIES, AND EFFECTIVENESS}

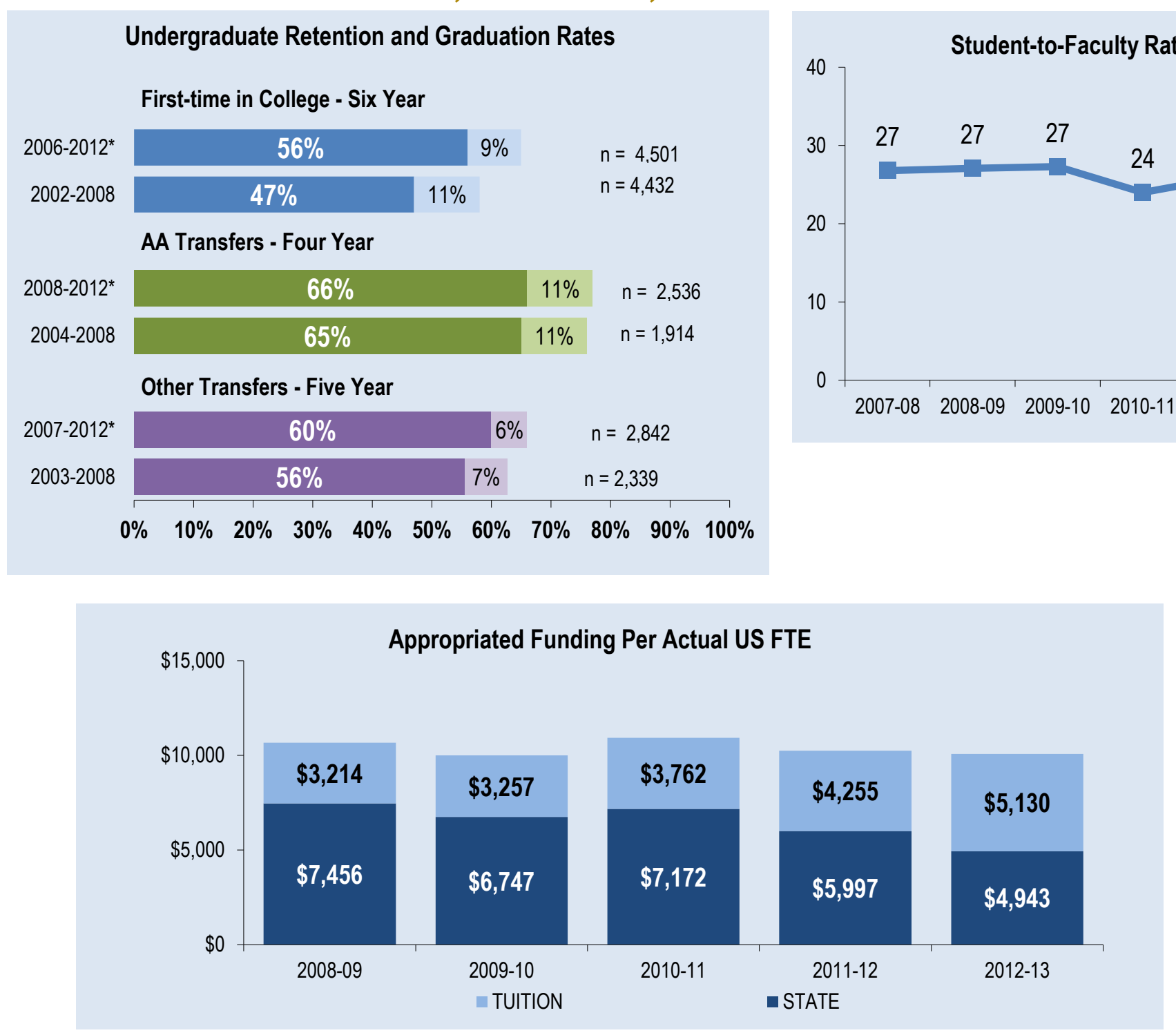




\section{Key Achievements}

Selected Accomplishments for ABC University (July 2011 - June 2012)

Limit to one page.

STUDENT AWARDS/ACHIEVEMENTS

See individual institution reports.

\section{FACULTY AWARDS/ACHIEVEMENTS}

See individual institution reports.

PROGRAM AWARDS/ACHIEVEMENTS

See individual institution reports.

\section{RESEARCH AWARDS/ACHIEVEMENTS}

See individual institution reports.

INSTITUTIONAL AWARDS/ACHIEVEMENTS

See individual institution reports. 


\section{Narrative}

Narrative must include the following subheaders.

Limit the entire narrative to a maximum of eight (8) pages.

Arial 11 point font.

\section{INTRODUCTION: THE USF SYSTEM}

The University of South Florida System, which includes USF Tampa (USF), USF St. Petersburg (USFSP), and USF Sarasota-Manatee (USFSM), catalyzes and coordinates initiatives at and among its interdependent institutions that develop graduates for 21st century careers; advance research, scholarship, and creative endeavors to improve the quality of life; and engage its communities for mutual benefit.

The institutions of the USF System (USF, USFSP, USFSM) have distinct missions and each has its own strategic plan. The USF System was formed to bring these three institutions together, so that collectively and collaboratively they could serve the region and beyond in optimal ways, resulting in a stronger presence and a distinctiveness that provides an unstoppable competitive differentiation. In addition to having a strong and unified voice for higher education, the USF System seeks to find and capitalize on synergies and economies of scale among its institutions that are of benefit to students, faculty, staff, alumni, and communities. All three institutions have separate IPEDS reporting. USF, USFSP and USFSM are accredited by SACS. By Carnegie classification, USF is a doctoral university with very high research activity and USFSP and USFSM are each classified as masters, medium level.

The members of the USF System together provide enhanced access and greater choice for students; broader advocacy; efficiencies, both academic and economic; commitment to meeting local needs; leveraging our combined strength through collaboration; and a unified brand yielding identity and impact.

The USF System serves more than 47,000 students, offering 237 degree programs: 86 bachelor's, 104 master's, 2 educational specialist, 41 research doctoral programs, and four professional doctorates. In 2011-12, the USF System awarded 12,154 degrees: Bachelor's 9,009; Master's 2,717; Specialist 12; Research Doctoral 271; and Professional Doctoral 145.

A brief summary report follows. Details of the individual institutional responses are found within the respective Annual Reports:

- USF Tampa Annual Accountability Report 2011-12, pp. 5-12

- USF St Petersburg Annual Accountability Report 2011-12, pp. 5-12

- USF Sarasota-Manatee Annual Accountability Report 2011-12, pp. 5-9

\section{ACCESS TO AND PRODUCTION OF DEGREES}

The USF System continues to provide access to an array of student experiences and a broad selection of degree programs. Collaborative degree programs, hosted programs, interdisciplinary initiatives, and undergraduate and graduate research opportunities leverage the resources of the System to increase student opportunities and foster student success. Activities at all USF System institutions focus on the recruitment and retention of top-level students and highly qualified faculty to enhance learning effectiveness and degree production, improve student retention, and raise graduation rates. 


\section{MEETING STATEWIDE PROFESSIONAL AND WORKFORCE NEEDS}

A stated goal of the USF System is to coordinate activities and promote synergies among its member institutions to create a major economic engine for the region and the state. The USF System offers an array of undergraduate and graduate degree programs preparing students to become leaders in business, industry, service, and research. Many degree programs align with state goals to meet professional and workforce needs, including education, health professions, the sciences, and emerging technologies.

\section{BUILDING WORLD-CLASS ACADEMIC PROGRAMS AND RESEARCH CAPACITY}

The institutions of the USF System continue to build both the number and quality of their distinctive degree programs and to make advances in research and innovation with total research expenditures for the USF System in 2010/11 exceeding \$344 million and federal expenditures exceeding \$221 million.

\section{MEETING COMMUNITY NEEDS AND FULFILLING UNIQUE INSTITUTIONAL RESPONSIBILITIES}

The USF System's mission statement includes a commitment to community engagement by facilitating increased collaborations among its member institutions and across the region. The USF System serves as a key unifying element for the region.

\section{PROGRESS ON PRIMARY INSTITUTIONAL GOALS AND METRICS (as outlined in University Work Plan)}

See individual institutional reports.

\section{ADDITIONAL INFORMATION ON QUALITY, RESOURCES, EFFICIENCIES AND EFFECTIVENESS}

See individual institutional reports. 


\section{Data Tables}

\section{FINANCIAL RESOURCES}

Table 1A. Education and General Revenues

Table 1B. Education and General Expenditures

Table 1C. Funding per Student FTE

Table 1D. Other Budget Entities

Table 1E. Voluntary Support of Higher Education

PERSONNEL

Table 2A. Personnel Headcount

ENROLLMENT AND SPACE

Table 3A. Full-time Equivalent (FTE) Enrollment

Table 3B. Enrollment by Location

Table 3C. Enrollment by Method of Instruction

UNDERGRADUATE EDUCATION

Table 4A. Baccalaureate Degree Program Changes in AY 2011-2012

Table 4B. Retention Rates

Table 4C. FTIC Graduation Rates (Full-time)

Table 4D. FTIC Graduation Rates (Full- and Part-time)

Table 4E. AA Transfers Graduation Rates

Table 4F. Other Transfers Graduation Rates

Table 4G. Baccalaureate Degrees Awarded

Table 4H. Baccalaureate Degrees Awarded in Areas of Strategic Emphasis

Table 4I. Baccalaureate Degrees Awarded to Underrepresented Groups

Table 4J. Baccalaureate Degrees Without Excess Credit Hours

Table 4K. Undergraduate Course Offerings

Table 4L. Faculty Teaching Undergraduates

Table 4M. Undergraduate Instructional Faculty Compensation

Table 4N. Student/Faculty Ratio

Table 4O. Licensure/Certification Exam: Nursing (NCLEX)

Table 4P. Tuition Differential Fee

\section{GRADUATE EDUCATION}

Table 5A. Graduate Degree Program Changes in AY 2011-2012

Table 5B. Graduate Degrees Awarded

Table 5C. Graduate Degrees Awarded in Areas of Strategic Emphasis

Table 5D. Licensure/Certification Exams for Graduate Programs

\section{RESEARCH \& ECONOMIC DEVELOPMENT}

Table 6A. Research and Development Expenditures

Table 6B. Centers of Excellence

Table 6C. State University Research Commercialization Assistance Grants

Table 6D. 21st Century World Class Scholars Program 
Section 1 - Financial Resources

TABLE 1A. University Education and General Revenues

\begin{tabular}{lrrrrr} 
& $\begin{array}{c}\mathbf{2 0 0 8 - 0 9} \\
\text { Actual }\end{array}$ & $\begin{array}{c}\mathbf{2 0 0 9 - 1 0} \\
\text { Actual }\end{array}$ & \multicolumn{1}{c}{$\begin{array}{c}\mathbf{2 0 1 0 - 1 1} \\
\text { Actual }\end{array}$} & $\begin{array}{c}\mathbf{2 0 1 1 - 1 2} \\
\text { Actual }\end{array}$ & $\begin{array}{r}\mathbf{2 0 1 2 - 1 3} \\
\text { Estimates }\end{array}$ \\
\hline MAIN OPERATIONS & & & & & \\
\hline Recurring State Funds & $\$ 269,447,277$ & $\$ 241,841,349$ & $\$ 262,674,613$ & $\$ 239,016,278$ & $\$ 180,136,985$ \\
\hline Non-Recurring State & $\$ 11,937,078$ & $\$ 1,585,518$ & $\$ 3,873,018$ & $\$ 2,656,583$ & $\$ 2,000,000$ \\
Funds & $\$ 112,352,760$ & $\$ 118,853,735$ & $\$ 129,324,373$ & $\$ 136,448,693$ & $\$ 143,207,335$ \\
\hline Tuition & $\$ 2,626,024$ & $\$ 7,458,495$ & $\$ 14,376,755$ & $\$ 22,361,250$ & $\$ 35,359,828$ \\
\hline Tuition Differential Fee & $\$ 3,862,283$ & $\$ 3,802,375$ & $\$ 3,364,814$ & $\$ 3,152,439$ & $\$ 3,578,099$ \\
\hline Misc. Fees \& Fines & $\$ 7,287,963$ & $\$ 7,304,874$ & $\$ 7,330,654$ & $\$ 7,334,170$ & $\$ 0$ \\
\hline Phosphate Research & $\$ 0$ & $\$ 18,790,945$ & $\$ 17,980,176$ & $\$ 0$ & $\$ 0$ \\
Trust Fund & $\mathbf{\$ 1 0 7 , 5 1 3 , 3 8 5}$ & $\mathbf{\$ 3 9 9 , 6 3 7 , 2 9 1}$ & $\mathbf{\$ 4 3 8 , 9 2 4 , 4 0 3}$ & $\mathbf{\$ 4 1 0 , 9 6 9 , 4 1 3}$ & $\mathbf{\$ 3 6 4 , 2 8 2 , 2 4 7}$
\end{tabular}

HEALTH SCIENCE CENTER / MEDICAL SCHOOL

\begin{tabular}{|c|c|c|c|c|c|}
\hline Recurring State Funds & $\$ 62,041,950$ & $\$ 61,549,150$ & $\$ 61,824,195$ & $\$ 63,127,971$ & $\$ 65,594,991$ \\
\hline $\begin{array}{l}\text { Non-Recurring State } \\
\text { Funds }\end{array}$ & $\$ 635,338$ & $\$ 0$ & $\$ 1,175,000$ & $\$ 250,000$ & $\$ 0$ \\
\hline Tuition & $\$ 26,347,362$ & $\$ 29,988,216$ & $\$ 32,942,009$ & $\$ 41,065,438$ & $\$ 50,531,236$ \\
\hline Tuition Differential Fee & $\$ 111,799$ & $\$ 501,511$ & 7,321 & ,703,379 & $\$ 2,174,157$ \\
\hline Misc. Fees \& Fines & $\$ 0$ & $\$ 1,331$ & $\$ 1,280$ & $\$ 2,568$ & $\$ 2,500$ \\
\hline $\begin{array}{l}\text { Dhosphate Research } \\
\text { Trust Fund }\end{array}$ & $\$ 0$ & $\$ 0$ & $\$ 0$ & $\$ 0$ & $\$ 0$ \\
\hline Federal Stimulus Funds & $\$ 0$ & $\$ 4,569,090$ & $\$ 4,351,772$ & $\$ 0$ & $\$ 0$ \\
\hline JBTOTAL & 136,449 & $\$ 96,609,298$ & $101,241,577$ & $106,149,356$ & $3,302,884$ \\
\hline
\end{tabular}

INSTITUTE OF FOOD \& AGRICULTURAL SCIENCES (IFAS) SUBTOTAL \$0 $\$ 0$ $\$ 0$ $\$ 0$

\section{TOTAL}

Recurring State Funds: State recurring funds include general revenue and lottery education \& general (E\&G) appropriations and any administered funds provided by the state, including annual adjustments of risk management insurance premiums for the estimated year. This does not include technical adjustments or transfers made by universities after the appropriation. Please note: for estimated 2012-13 this figure includes the non-recurring $\$ 300 \mathrm{M}$ system budget reduction. - Source: For actual years, SUS Final Amendment Packages; for estimated year the 2012-13 Allocation Summary and Workpapers (Total E\&G general revenue \& lottery minus non-recurring) and Board of Governors staff calculations for risk management insurance adjustments. Non-Recurring State Funds: State non-recurring funds include general revenue and lottery education \& general appropriations and any administered funds provided by the state. This does not include technical adjustments or transfers made by Universities after the appropriation - Source: non-recurring appropriations section of the annual Allocation Summary and Workpapers document and all other non-recurring budget amendments allocated later in the fiscal year. Tuition: Actual resident \& non-resident tuition revenues collected from students, net of fee waivers. - Source: Operating Budget, Report 625 - Schedule I-A. Tuition Differential Fee: Actual tuition differential revenues collected from undergraduate students - Source: Operating Budget, Report 625 - Schedule I-A. Miscellaneous Fees \& Fines: Other revenue collections include items such as application fees, late registration fees, library fines, miscellaneous revenues. This is the total revenue from Report 625 minus tuition and tuition differential fee revenues. This does not include local fees - Source: Operating Budget, Report 625 - Schedule I-A. Phosphate Research Trust Fund: State appropriation for the Florida Industrial and Phosphate Research Institute at the University of South Florida (for history years through 2011-12); beginning 2012-13 the Phosphate Research Trust Fund is appropriated through Florida Polytechnic University. Other Operating Trust Funds- For UF-IFAS and UF-HSC, actual revenues from the Incidental Trust Funds and Operations \& Maintenance Trust Fund are provided by the University of Florida. Source: Final Amendment Package. Federal Stimulus Funds: Non-recurring American Recovery and Reinvestment Act funds appropriated by the state - Source: SUS Final Amendment Package. 
Section 1 - Financial Resources (continued)

TABLE 1B. University Education and General Expenditures

\begin{tabular}{lrrrrr} 
& $\begin{array}{c}\mathbf{2 0 0 8 - 0 9} \\
\text { Actual }\end{array}$ & $\begin{array}{c}\mathbf{2 0 0 9 - 1 0} \\
\text { Actual }\end{array}$ & $\begin{array}{c}\mathbf{2 0 1 0 - 1 1} \\
\text { Actual }\end{array}$ & $\begin{array}{c}\mathbf{2 0 1 1 - 1 2} \\
\text { Actual }\end{array}$ & $\begin{array}{c}\mathbf{2 0 1 2 - 1 3} \\
\text { Estimates }\end{array}$ \\
\hline MAIN OPERATIONS & & & & & \\
\hline Instruction/Research & $\$ 232,420,538$ & $\$ 248,178,440$ & $\$ 264,299,730$ & $\$ 259,669,538$ & $\$ 267,947,261$ \\
\hline Administration \& Support & $\$ 28,501,983$ & $\$ 23,730,020$ & $\$ 26,484,388$ & $\$ 26,751,015$ & $\$ 19,109,484$ \\
PO\&M & $\$ 36,124,122$ & $\$ 35,302,128$ & $\$ 34,678,763$ & $\$ 35,363,017$ & $\$ 39,616,212$ \\
\hline Student Services & $\$ 22,054,934$ & $\$ 21,924,396$ & $\$ 21,251,998$ & $\$ 19,336,600$ & $\$ 17,125,241$ \\
\hline Institutes \& Research Ctrs. & $\$ 1,024,089$ & $\$ 968,072$ & $\$ 721,815$ & $\$ 3,543,080$ & $\$ 2,335,769$ \\
Radio/TV & $\$ 81,056$ & $\$ 892,243$ & $\$ 890,441$ & $\$ 945,518$ & $\$ 925,464$ \\
Library/Audio Visual & $\$ 14,141,123$ & $\$ 14,667,694$ & $\$ 13,622,890$ & $\$ 14,036,909$ & $\$ 14,019,664$ \\
\hline Museums and Galleries & $\$ 729,951$ & $\$ 640,699$ & $\$ 702,092$ & $\$ 738,589$ & $\$ 629,193$ \\
\hline Agricultural Extension & $\$ 0$ & $\$ 0$ & $\$ 0$ & $\$ 0$ & $\$ 0$ \\
Intercollegiate Athletics & $\$ 352,411$ & $\$ 356,212$ & $\$ 358,193$ & $\$ 368,234$ & $\$ 371,389$ \\
\hline Acad. Infrastructure Sprt Org & $\$ 0$ & $\$ 0$ & $\$ 181,684$ & $\$ 875,239$ & $\$ 2,202,570$ \\
\hline SUBTOTAL & $\mathbf{3 3 6 , 1 6 4 , 2 0 7}$ & $\mathbf{\$ 3 4 6 , 6 5 9 , 9 0 4}$ & $\mathbf{\$ 3 6 3 , 1 9 1 , 9 9 4}$ & $\mathbf{\$ 3 6 1 , 6 2 7 , 7 3 9}$ & $\mathbf{\$ 3 6 4 , 2 8 2 , 2 4 7}$
\end{tabular}

HEALTH SCIENCE CENTER / MEDICAL SCHOOL

\begin{tabular}{lrrrrr}
\hline Instruction/Research & $\$ 64,047,565$ & $\$ 68,082,738$ & $\$ 76,521,544$ & $\$ 76,382,108$ & $\$ 104,731,564$ \\
\hline Administration \& Support & $\$ 4,463,186$ & $\$ 5,033,768$ & $\$ 6,375,343$ & $\$ 5,076,837$ & $\$ 6,957,364$ \\
PO\&M & $\$ 262,695$ & $\$ 84,684$ & $\$ 1,373,059$ & $\$ 1,800,847$ & $\$ 4,324,443$ \\
\hline Teaching Hospital & $\$ 0$ & $\$ 0$ & $\$ 0$ & $\$ 0$ & $\$ 0$ \\
\& Allied Clinics & $\$ 2,787,282$ & $\$ 2,473,154$ & $\$ 2,437,820$ & $\$ 3,043,160$ & $\$ 2,289,513$ \\
Library/Audio Visual & $\$ 1,153$ & $\$ 0$ & $\$ 1,640$ & $\$ 0$ & $\$ 0$ \\
Acad. Infrastructure Sprt Org. & $\$ 0$ & $\$ 0$ & $\$ 0$ & $\$ 0$ & $\$ 0$ \\
Student Services & $\$ 71,561,881$ & $\mathbf{\$ 7 5 , 6 7 4 , 3 4 4}$ & $\mathbf{\$ 8 6 , 7 0 9 , 4 0 6}$ & $\mathbf{\$ 8 6 , 3 0 2 , 9 5 2}$ & $\mathbf{\$ 1 1 8 , 3 0 2 , 8 8 4}$
\end{tabular}

\section{INSTITUTE OF FOOD \& AGRICULTURAL SCIENCES (IFAS) $\begin{array}{llllll}\text { SUBTOTAL } & \$ 0 & \$ 0 & \$ 0 & \$ 0 & \$ 0\end{array}$}

\section{TOTAL}

The table reports the actual and estimated amount of expenditures from revenues appropriated by the legislature for each fiscal year. The expenditures are classified by Program Component (i.e., Instruction/Research, PO\&M, Administration, etc...) for activities directly related to instruction, research and public service. The table does not include expenditures classified as non-operating expenditures (i.e., to service assetrelated debts), and therefore excludes a small portion of the amount appropriated each year by the legislature. Also, the table does not include expenditures from funds carried forward from previous years. Instruction \& Research: Includes expenditures for state services related to the instructional delivery system for advanced and professional education. Includes functions such as; all activities related to credit instruction that may be applied toward a postsecondary degree or certificate; non-project research and service performed to maintain professional effectives; individual or project research; academic computing support; academic source or curriculum development. Source: Operating Budget Summary - Expenditures by Program Activity (or Report 645). Administration \& Support Services: Expenditures related to the executive direction and leadership for university operations and those internal management services which assist and support the delivery of academic programs. Source: Operating Budget Summary - Expenditures by Program Activity (or Report 645). PO\&M: Plant Operations \& Maintenance expenditures related to the cleaning and maintenance of existing grounds, the providing of utility services, and the planning and design of future plant expansion and modification Source: Operating Budget Summary - Expenditures by Program Activity (or Report 645). Student Services: Includes resources related to physical, psychological, and social well being of the student. Includes student service administration, social and cultural development, counseling and career guidance, financial aid, and student admissions and records. Source: Operating Budget Summary - Expenditures by Program Activity (or Report 645). 
Section 1 - Financial Resources (continued)

TABLE 1C. State Funding per Full-Time Equivalent (FTE) Student

$\begin{array}{ccccc}2008-09 & 2009-10 & 2010-11 & 2011-12 & 2012-13 \\ \text { Actual } & \text { Actual } & \text { Actual } & \text { Actual } & \text { Estimates }\end{array}$

Appropriated Funding per FTE

General Revenue per FTE

Lottery Funds per FTE

Tuition \& Fees per FTE

Other Trust Funds per FTE

Total per FTE

$\begin{array}{rr}\$ 6,493 & \$ 5,424 \\ \$ 775 & \$ 670 \\ \$ 3,214 & \$ 3,257 \\ \$ 188 & \$ 653 \\ \$ 10,670 & \$ 10,004\end{array}$

$\$ 6,493$

3,214

$\$ 10,670$
Actual

Actual
Estimates

\section{Actual Funding per FTE}

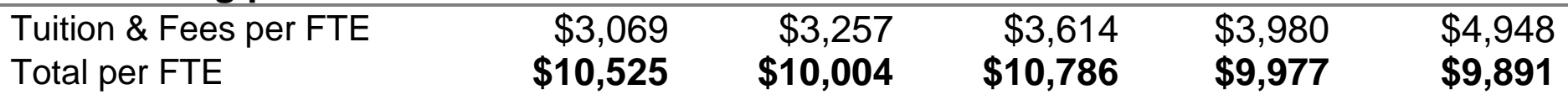

Notes: (1) FTE is based on actual FTE, not funded FTE; (2) does not include Health-Science Center funds or FTE; (3) FTE for these metrics uses the standard IPEDS definition of FTE, equal to 30 credit hours for undergraduates and 24 for graduates; and (4) actual funding per student is based on actual tuition and E\&G fees (does not include local fees) collected. Sources: Appropriated totals from the annual Final Amendment Package data. Estimated year data from the Allocation Summary document. Actual Student Fees from the Operating Budget 625 reports. This does not include appropriations for special units (i.e., IFAS, Health Science Centers, and Medical Schools). Tuition and fee revenues include tuition and tuition differential fee and E\&G fees (i.e., application, late registration, and library fees/fines). Other local fees that do not support E\&G activities are not included here (see Board of Governors Regulation 7.003). This data is not adjusted for inflation.

TABLE 1D. University Other Budget Entities

$\begin{array}{ccccc}2008-09 & 2009-10 & 2010-11 & 2011-12 & 2012-13 \\ \text { Actual } & \text { Actual } & \text { Actual } & \text { Actual } & \text { Estimates }\end{array}$

Auxiliary Enterprises

$\begin{array}{llllll}\text { Revenues } & \$ 171,361,009 & \$ 142,802,349 & \$ 159,279,590 & \$ 166,196,465 & \$ 173,389,267 \\ \text { Expenditures } & \$ 240,123,445 & \$ 115,485,207 & \$ 128,022,768 & \$ 136,665,186 & \$ 169,285,660\end{array}$

Contracts \& Grants

\begin{tabular}{|c|c|c|c|c|c|}
\hline Revenues & $\$ 346,300,000$ & $\$ 296,910,481$ & $\$ 280,658,090$ & $\$ 253,155,100$ & $\$ 377,818,271$ \\
\hline $\begin{array}{l}\text { Expenditures } \\
\text { ocal Funds }\end{array}$ & $\$ 340,000,000$ & $\$ 300,467,449$ & $\$ 305,640,232$ & $\$ 309,631,943$ & $\$ 386,434,278$ \\
\hline Revenues & $\$ 135,058,791$ & $\$ 408,521,266$ & $\$ 442,397,152$ & $\$ 445,195,357$ & $\$ 443,452,290$ \\
\hline $\begin{array}{l}\text { Expenditures } \\
\text { aculty Practice }\end{array}$ & $\$ 153,572,417$ & $\$ 406,432,437$ & $\$ 440,842,216$ & $\$ 444,874,605$ & $\$ 455,023,794$ \\
\hline Revenues & $\$ 150,206,988$ & $\$ 174,727,927$ & $\$ 183,622,430$ & & $\$ 194,642,509$ \\
\hline Expenditures & $\$ 156,641,074$ & $\$ 173,643,913$ & $\$ 182,116,435$ & $\$ 110,473,344$ & $\$ 114,393,325$ \\
\hline
\end{tabular}

Notes: Revenues do not include transfers. Expenditures do not include non-operating expenditures. Auxiliary Enterprises are self supported through fees, payments and charges. Examples include housing, food services, bookstores, parking services, health centers. Contract \& Grants resources are received from federal, state or private sources for the purposes of conducting research and public service activities. Local Funds are associated with student activity (supported by the student activity fee), student financial aid, concessions, intercollegiate athletics, technology fee, green fee, and student life \& services fee. Faculty Practice Plan revenues/receipts are funds generated from faculty practice plan activities. Faculty Practice Plan expenditures include all expenditures relating to the faculty practice plans, including transfers between other funds and/or entities. This may result in double counting in information presented within the annual report. Source: Operating Budget, Report 615. 


\section{Section 1 - Financial Resources (continued)}

\section{TABLE 1E. Voluntary Support of Higher Education}

\begin{tabular}{cccccc} 
& $\mathbf{2 0 0 6 - 0 7}$ & $\mathbf{2 0 0 7 - 0 8}$ & $\mathbf{2 0 0 8 - 0 9}$ & $\mathbf{2 0 0 9 - 1 0}$ & $\mathbf{2 0 1 0 - 1 1}$ \\
\hline $\begin{array}{c}\text { Endowment Value } \\
(\$ 1000 \text { s) }\end{array}$ & $\$ 388,516$ & $\$ 360,035$ & $\$ 275,398$ & $\$ 295,921$ & $\$ 344,000$ \\
\hline Gifts Received $(\$ s)$ & $\$ 56,826,407$ & $\$ 44,682,695$ & $\$ 34,010,969$ & $\$ 36,385,343$ & $\$ 81,500,000$ \\
\hline $\begin{array}{c}\text { Percentage of } \\
\text { Alumni Donors }\end{array}$ & $4.8 \%$ & $8.2 \%$ & $8.0 \%$ & $9.7 \%$ & $10.0 \%$ \\
\hline
\end{tabular}

Notes: Endowment value at the end of the fiscal year, as reported in the annual NACUBO Endowment Study. Gifts Received as reported in the Council for Aid to Education's Voluntary Support of Education (VSE) survey in the section entitled "Gift Income Summary," this is the sum of the present value of all gifts (including outright and deferred gifts) received for any purpose and from all sources during the fiscal year, excluding pledges and bequests. (There's a deferred gift calculator at www.cae.org/vse.) The present value of non-cash gifts is defined as the tax deduction to the donor as allowed by the IRS. Percentage of Alumni Donors as reported in the Council for Aid to Education's Voluntary Support of Education (VSE) survey in the section entitled "Additional Details," this is the number of alumni donors divided by the total number of alumni, as of the end of the fiscal year. "Alumni," as defined in this survey, include those holding a degree from the institution as well as those who attended the institution but did not earn a degree. 


\section{Section 2 - Personnel}

\section{TABLE 2A. Personnel Headcount (in Fall term only)}

\begin{tabular}{|c|c|c|c|c|c|}
\hline & 2007 & 2008 & 2009 & 2010 & 2011 \\
\hline \multicolumn{6}{|l|}{ Full-time Faculty } \\
\hline Tenured Faculty & 732 & 727 & 755 & 773 & 755 \\
\hline Tenure-track Faculty & 443 & 376 & 360 & 369 & 387 \\
\hline Non-Tenure Track Faculty & 582 & 476 & 503 & 523 & 501 \\
\hline Instructors Without Faculty Status & 0 & 0 & 0 & 0 & 0 \\
\hline Graduate Assistants/Associates & 0 & 0 & 0 & 0 & 0 \\
\hline Executive/Administrative & 568 & 568 & 634 & 686 & 726 \\
\hline Other Professional & 1,715 & 1,710 & 1,735 & 1,809 & 1,868 \\
\hline Non-Professional & 1,801 & 1,731 & 1,721 & 1,789 & 1,809 \\
\hline FULL-TIME SUBTOTAL & 5,841 & 5,588 & 5,708 & 5,949 & 6,046 \\
\hline \multicolumn{6}{|l|}{ Part-time Faculty } \\
\hline Tenured Faculty & 60 & 56 & 58 & 54 & 47 \\
\hline Tenure-track Faculty & 19 & 25 & 21 & 25 & 21 \\
\hline Non-Tenure Track Faculty & 170 & 154 & 150 & 235 & 381 \\
\hline Instructors Without Faculty Status & 0 & 0 & 0 & 0 & 0 \\
\hline Graduate Assistants/Associates & 1,725 & 1,774 & 1,866 & 2,071 & 2,059 \\
\hline Executive/Administrative & 19 & 15 & 17 & 16 & 20 \\
\hline Other Professional & 93 & 72 & 90 & 132 & 81 \\
\hline Non-Professional & 41 & 40 & 98 & 286 & 110 \\
\hline PART-TIME SUBTOTAL & 2,127 & 2,136 & 2,300 & 2,816 & 2,719 \\
\hline TOTAL & 8,098 & 7,877 & 8,160 & 8,239 & 8,765 \\
\hline
\end{tabular}

Note: This table is based on the annual IPEDS Human Resources Survey, and provides full- and part-time medical and non-medical staff by faculty status and primary function/occupational activity. Tenured and Tenure-Track Faculty include those categorized within instruction, research, or public service. Non-Tenure Track Faculty includes adjunct faculty and faculty on multi-year contracts categorized within instruction, research, or public service. Instructors Without Faculty Status includes postdoctoral research associates, and individuals hired as a staff member primarily to do research on a 3-year contract without tenure eligibility categorized within instruction, research, or public service. Executive/Administrative refers to all executive, administrative and managerial positions regardless of faculty status. Other Professional refers to support and service positions regardless of faculty status. 


\section{Section 3 - Enrollment}

\section{TABLE 3A. Full-Time Equivalent (FTE) Enrollment}

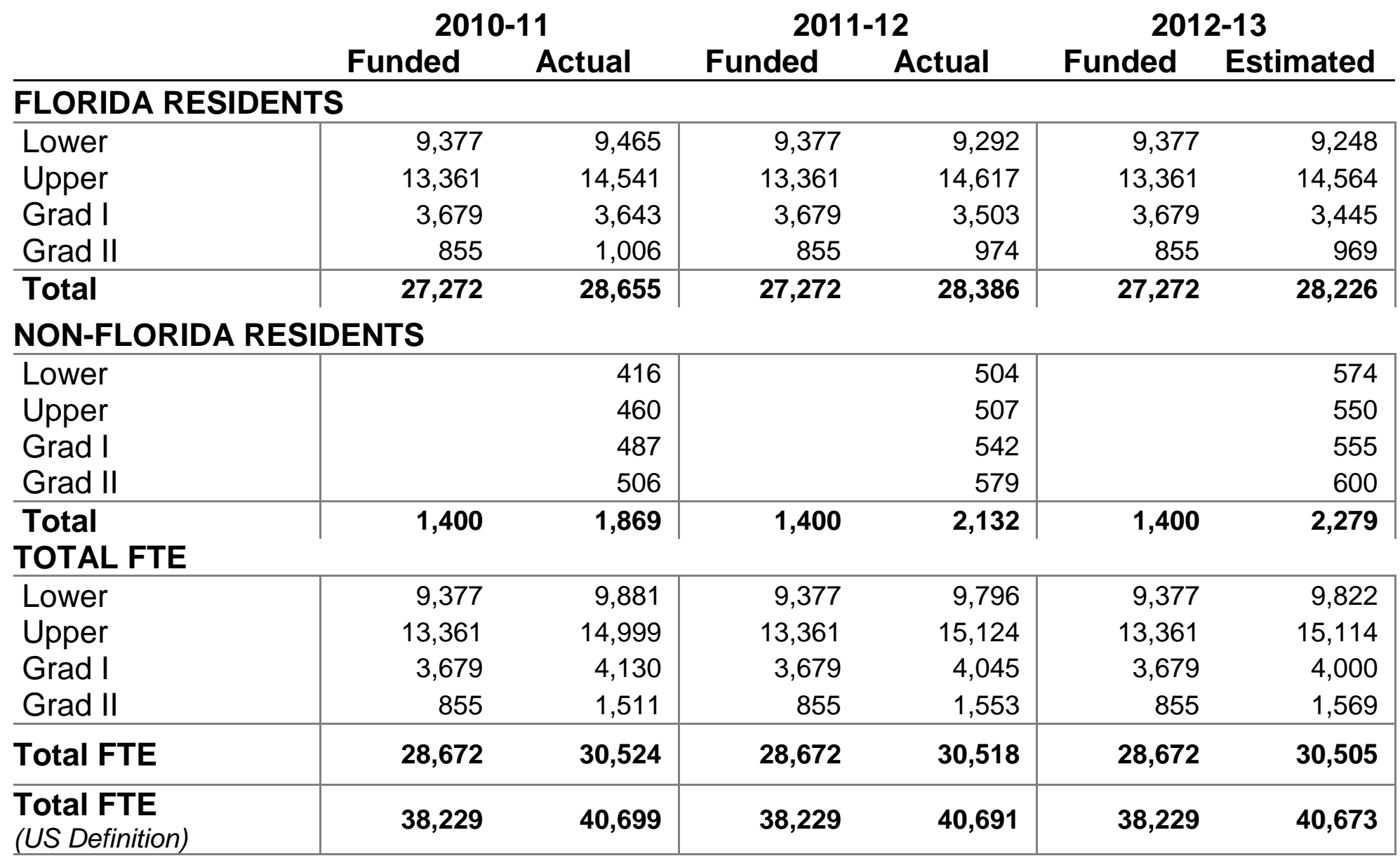

Headcount for Medical Doctorates

\begin{tabular}{|c|c|c|c|c|c|c|}
\hline Residents & 480 & 449 & 480 & 444 & 480 & 436 \\
\hline Non-Residents & 0 & 24 & 0 & 39 & 0 & 44 \\
\hline Total & 480 & 473 & 480 & 483 & 480 & 480 \\
\hline \multicolumn{7}{|c|}{ Headcount for Pharm D } \\
\hline Residents & 0 & 0 & 50 & 53 & 125 & 125 \\
\hline Non-Residents & 0 & 0 & 0 & 0 & 0 & 0 \\
\hline Total & 0 & 0 & 50 & 53 & 125 & 125 \\
\hline
\end{tabular}

Notes: Full-time Equivalent (FTE) student is a measure of instructional effort (and student activity) that is based on the number of credit hours that students enroll. FTE is based on the Florida definition, which divides undergraduate credit hours by 40 and graduate credit hours by 32 (US definition based on Undergraduate FTE $=30$ and Graduate FTE $=24$ credit hours). Funded enrollment as reported in the General Appropriations Act and set by the legislature. Actual enrollment only reports 'state-fundable' FTE as reported by Universities to the Board of Governors in the Student Instruction File (SIF). Estimated enrollment as reported by Universities to the Board of Governors in their Enrollment Plans. Actual Medical headcounts (includes Medicine, Dentistry, and Veterinary programs) are based on Fall enrollment data. 
Section 3 - Enrollment (continued)

TABLE 3B. Full-Time Equivalent (FTE) Enrollment by Location

\begin{tabular}{|c|c|c|c|}
\hline & $\begin{array}{c}2010-11 \\
\text { Actual }\end{array}$ & $\begin{array}{c}\text { 2011-12* } \\
\text { Actual }\end{array}$ & $\begin{array}{l}\text { 2012-13* } \\
\text { Estimated }\end{array}$ \\
\hline \multicolumn{4}{|c|}{ MAIN CAMPUS (*includes USF in Lakeland) } \\
\hline Lower & 8425 & 8203 & 8173 \\
\hline Upper & 10631 & 11292 & 11114 \\
\hline Master's (Grad I) & 2675 & 2622 & 2622 \\
\hline Doctoral ( Grad III) & 1214 & 1237 & 1270 \\
\hline TOTAL & 22,945 & 23,354 & 23,179 \\
\hline \multicolumn{4}{|c|}{ SITE: Health Science Center } \\
\hline Lower & 386 & 394 & 395 \\
\hline Upper & 953 & 1119 & 1203 \\
\hline Master's (Grad I) & 976 & 1046 & 997 \\
\hline Doctoral (Grad II) & 295 & 315 & 299 \\
\hline TOTAL & 2,610 & 2,874 & 2,894 \\
\hline \multicolumn{4}{|c|}{ SITE: Polytechnic } \\
\hline Lower & 57 & na & na \\
\hline Upper & 750 & na & na \\
\hline Master's (Grad I) & 94 & na & na \\
\hline Doctoral (Grad II) & 0 & na & na \\
\hline TOTAL & 901 & na & na \\
\hline \multicolumn{4}{|c|}{ SITE: Sarasota-Manatee } \\
\hline Lower & 66 & 110 & 150 \\
\hline Upper & 927 & 912 & 968 \\
\hline Master's (Grad I) & 121 & 106 & 110 \\
\hline Doctoral (Grad II) & 2 & 0 & 0 \\
\hline TOTAL & 1,116 & 1,128 & 1,228 \\
\hline \multicolumn{4}{|c|}{ SITE: St. Petersburg } \\
\hline Lower & 947 & 1089 & 1104 \\
\hline Upper & 1662 & 1733 & 1757 \\
\hline Master's (Grad I) & 260 & 266 & 271 \\
\hline Doctoral (Grad II) & 1 & 1 & 0 \\
\hline TOTAL & 2,870 & 3,089 & 3,132 \\
\hline \multicolumn{4}{|c|}{ SITE: Remaining Physical Locations } \\
\hline Lower & 0 & 0 & 0 \\
\hline Upper & 78 & 68 & 72 \\
\hline Master's (Grad I) & 4 & 5 & .0 \\
\hline Doctoral (Grad II) & 0 & 0 & 0 \\
\hline TOTAL & 82 & 73 & 72 \\
\hline
\end{tabular}




\section{TABLE 3B. Full-Time Equivalent (FTE) Enrollment by Location}

\section{TOTAL}

\begin{tabular}{|c|c|c|c|}
\hline Lower & 9881 & 9796 & 9822 \\
\hline Upper & 15001 & 15124 & 15114 \\
\hline Master's (Grad I) & 4130 & 4045 & 4000 \\
\hline Doctoral (Grad II) & 1512 & 1553 & 1569 \\
\hline TOTAL & 30,524 & 30,518 & 30,505 \\
\hline
\end{tabular}

Notes: "Site" refers to each distinct physical location that has or is planned to have more than 150 State-fundable FTE enrollments. See table $3 C$ for more details on Distance Learning. Total equals totals in table $3 \mathrm{~A}$. 


\section{Section 3 - Enrollment (continued)}

TABLE 3C. Full-Time Equivalent (FTE) Enrollment by Method of Instruction

2010-11

2011-12

\section{LOWER-DIVISION}

Traditional (<50\%)

8,301

8,140

Hybrid Blend (50\%-79\%)

22

48

Distance Learning (>80\%)

1,557

1,607

TOTAL

9,880

9,795

\section{UPPER-DIVISION}

Traditional (<50\%)

Hybrid Blend (50\%-79\%)

Distance Learning (>80\%)

TOTAL
11,259

330

3,411

15,000
10,948

352

3,821

15,121

\section{MASTER'S (GRAD I)}

Traditional (<50\%)

2,888

134

Hybrid Blend (50\%-79\%)

Distance Learning (>80\%)

TOTAL
1,108

4,130
2,863

147

1,034

4,044

\section{DOCTORAL (GRAD II)}

Traditional (<50\%)

Hybrid Blend (50\%-79\%)

Distance Learning (>80\%)

TOTAL
1,453

9

50

1,512
1,491

5

62

\section{TOTAL}

Traditional (<50\%)

23,901

495

6,125

30,521
1,558
Hybrid Blend (50\%-79\%)

Distance Learning (>80\%)

TOTAL

Note: Full-time Equivalent (FTE) student is a measure of instructional effort (and student activity) that is based on the number of credit hours that students enroll. FTE is based on the Florida definition, which divides undergraduate credit hours by 40 and graduate credit hours by 32 . Distance Learning is a course in which at least 80 percent of the direct instruction of the course is delivered using some form of technology when the student and instructor are separated by time or space, or both (per 1009.24(17), F.S.). Hybrid is a course where $50 \%$ to $79 \%$ of the instruction is delivered using some form of technology, when the student and instructor are separated by time or space, or both (per SUDS data element 2052). Traditional (and Technology Enhanced) refers to primarily face to face instruction utilizing some form of technology for delivery of supplemental course materials for no more than $49 \%$ of instruction (per SUDS data element 2052). 


\section{Section 4 - Undergraduate Education}

\section{TABLE 4A. Baccalaureate Degree Program Changes in AY 2011-12}

\begin{tabular}{|c|c|c|c|c|c|}
\hline Title of Program & $\begin{array}{c}\text { Six-digit } \\
\text { CIP } \\
\text { Code }\end{array}$ & $\begin{array}{c}\text { Degree } \\
\text { Level }\end{array}$ & $\begin{array}{l}\text { Date of } \\
\text { UBOT } \\
\text { Action }\end{array}$ & $\begin{array}{l}\text { Starting } \\
\text { or Ending } \\
\text { Term }\end{array}$ & Comments \\
\hline \multicolumn{6}{|l|}{ New Programs } \\
\hline Biology & 26.0101 & Bachelor & Jun. 11, 2012 & Fall 2012 & St. Petersburg \\
\hline Speech Language Services & 52.0201 & Bachelor & Jun. 11, 2012 & Spring 2012 & $\begin{array}{l}\text { Sarasota- } \\
\text { Manatee }\end{array}$ \\
\hline Health Science & 51.0000 & Bachelor & Mar. 12, 2012 & Fall 2012 & Tampa \\
\hline Global Business & 52.1101 & Bachelor & Oct. 12, 2012 & Fall 2012 & St. Petersburg \\
\hline \multicolumn{6}{|l|}{ Terminated Programs } \\
\hline Art Teacher Ed & 13.1302 & Bachelor & Jun. 11, 2012 & Summer 2011 & Tampa \\
\hline Business Teacher Ed (Voc) & 13.1303 & Bachelor & Jun. 11, 2012 & Spring 2007 & Tampa \\
\hline Dance Education & 13.1324 & Bachelor & Jun. 11, 2012 & Summer 2011 & Tampa \\
\hline Ed of the Emotionally Handicap & 13.1005 & Bachelor & Jun. 11, 2012 & Spring 2005 & Tampa \\
\hline Ed of the Mentally Handicapped & 13.1006 & Bachelor & Jun. 11, 2012 & Spring 2007 & Tampa \\
\hline Ed of Specific Learning Disabled & 13.1011 & Bachelor & Jun. 11, 2012 & Spring 2005 & Tampa \\
\hline Engineering & 14.0101 & Bachelor & Jun. 11, 2012 & Spring 2011 & Tampa \\
\hline Liberal Arts \& Studies & 24.0101 & Bachelor & Jun. 11, 2012 & Spring 2009 & Tampa \\
\hline Trade and Industrial Teacher Ed & 13.132 & Bachelor & Jun. 11, 2012 & Spring 2008 & Tampa \\
\hline \multicolumn{6}{|l|}{ Inactive Programs } \\
\hline None & & & & & \\
\hline \multicolumn{6}{|c|}{ New Programs Considered By University But Not Approved } \\
\hline \multicolumn{6}{|l|}{ None } \\
\hline
\end{tabular}

Note: This table does not include new majors or concentrations added under an existing degree program CIP Code. This table reports the program changes between May 5, 2011 and May 4, 2012. New Programs are proposed new degree programs that have been completely through the approval process at the university and, if appropriate, the Board of Governors. Does not include new majors or concentrations added under an existing degree program CIP Code. Terminated Programs are degree programs for which the entire CIP Code has been terminated and removed from the university's inventory of degree programs. Does not include majors or concentrations terminated under an existing degree program CIP Code if the code is to remain active on the academic degree inventory. Inactive Programs are degree programs for which enrollments have been temporarily suspended for the entire CIP Code, but the program CIP Code has not been terminated. Does not include majors or concentrations suspended under an existing degree program CIP Code if the code is to remain active on the academic degree inventory and new enrollments in any active major will be reported. New Programs Considered by University But Not Approved includes any programs considered by the university board of trustees, or any committee of the board, but not approved for implementation. Also include any programs that were returned prior to board consideration by the university administration for additional development, significant revisions, or re-conceptualization; regardless of whether the proposal was eventually taken to the university board for approval. Count the returns once per program, not multiple times the proposal was returned for revisions, unless there is a total re-conceptualization that brings forward a substantially different program in a different CIP Code. 


\title{
Section 4 - Undergraduate Education (continued)
}

\author{
TABLE 4B. Retention Rates \\ Full-time FTIC Retained in the Second Fall Term at Same University
}

\begin{tabular}{cccccc} 
& $\mathbf{2 0 0 7 - 0 8}$ & $\mathbf{2 0 0 8 - 0 9}$ & $\mathbf{2 0 0 9 - 1 0}$ & $\mathbf{2 0 0 1 0 - 1 1}$ & $\begin{array}{c}\mathbf{2 0 1 1 - 1 2} \\
\text { Preliminary }\end{array}$ \\
\hline Cohort Size & 4,142 & 4,395 & 4,306 & 4,951 & 4,027 \\
\hline \% Retained & $87 \%$ & $86 \%$ & $87 \%$ & $85 \%$ & $86 \%$ \\
\hline $\begin{array}{c}\text { \% Retained } \\
\text { with GPA of 2.0 or higher }\end{array}$ & $81 \%$ & $83 \%$ & $84 \%$ & $82 \%$ & $85 \%$
\end{tabular}

Notes: Cohorts are based on undergraduate students who enter the institution in the Fall term (or Summer term and continue into the Fall term). Percent Retained is based on student enrollment in the Fall term following their first year. Percent Retained with GPA Above 2.0 is based on student enrollment in the Fall term following their first years for those students with a GPA of 2.0 or higher at the end of their first year (Fall, Spring, Summer). The most recent year of Retention data is based on preliminary data (SIFP file) that is comparable to the final data (SIF file) but may be revised in the following years based on changes in student cohorts.

TABLE 4C. FTIC Graduation Rates for Full-Time, First-Time-in-College (FTIC) Undergraduate Students at Same University

Term of Entry

\begin{tabular}{|c|c|c|c|c|c|}
\hline Cohort Size & 4,205 & 4,941 & 4,140 & 4,101 & 4,399 \\
\hline$\%$ Graduated & $48 \%$ & $48 \%$ & $53 \%$ & $53 \%$ & $57 \%$ \\
\hline$\%$ Still Enrolled & $11 \%$ & $11 \%$ & $9 \%$ & $9 \%$ & $9 \%$ \\
\hline$\%$ Success Rate & $59 \%$ & $59 \%$ & $62 \%$ & $62 \%$ & $65 \%$ \\
\hline \multicolumn{6}{|c|}{$\begin{array}{l}\text { Notes: Cohorts are based on undergraduate students who enter the institution in the Fall term (or Summer term and continue into the Fall term). Percent } \\
\text { Graduated is based on federal rate and does not include students who originally enroll as part-time students, or who transfer into the institution. This } \\
\text { metric complies with the requirements of the federal Student Right to Know Act that requires institutions to report the completion status at } 150 \% \text { of normal } \\
\text { time (or six years). Success Rate measures the percentage of an initial cohort of students who have either graduated or are still enrolled at the same } \\
\text { university. Since degrees can be awarded after the last semester of coursework, the most recent year of data in this table provides preliminary data that } \\
\text { may change with the addition of "late degrees". Late degrees reported in conjunction with the IPEDS Graduation Rate Survey due in mid-April will be } \\
\text { reflected in the following year. }\end{array}$} \\
\hline
\end{tabular}




\section{Section 4 - Undergraduate Education (continued)}

TABLE 4D. FTIC Progression and Graduation Rates

\begin{tabular}{cccccc}
$\mathbf{4}$ - Year Rates & $\mathbf{2 0 0 4 - 0 8}$ & $\mathbf{2 0 0 5 - 0 9}$ & $\mathbf{2 0 0 6 - 1 0}$ & $\mathbf{2 0 0 7 - 1 1}$ & $\begin{array}{c}\mathbf{2 0 0 8 - 1 2} \\
\text { Preliminary }\end{array}$ \\
\hline Full- \& Part-time Cohort & 4,715 & 4,478 & 4,501 & 4,216 & 4,482
\end{tabular}

From Same University

$\%$ Graduated

$23 \%$

$24 \%$

$28 \%$

$34 \%$

$37 \%$

\% Still Enrolled

$43 \%$

$41 \%$

$41 \%$

$40 \%$

$38 \%$

From Other SUS University

$\begin{array}{lccccc}\% \text { Graduated } & 2 \% & 2 \% & 1 \% & 1 \% & 1 \% \\ \% \text { Still Enrolled } & 5 \% & 3 \% & 3 \% & 3 \% & 3 \%\end{array}$

From State University System

$\%$ Graduated

$\%$ Still Enrolled

$\%$ Success Rate
$25 \%$

$48 \%$

$72 \%$
$25 \%$

$45 \%$

$70 \%$
$30 \%$

$44 \%$

$73 \%$
$36 \%$

$43 \%$

$78 \%$
$38 \%$

$41 \%$

$79 \%$

\section{6 - Year Rates}

2002-08

2003-09

2004-10

Full- \& Part-time Cohort

4,432

5,177

4,669

2005-11

2006-12

Preliminary

From Same University

$\%$ Graduated

$47 \%$

$11 \%$

$47 \%$

$11 \%$

$52 \%$

$10 \%$

$52 \%$

$9 \%$

$56 \%$

$9 \%$

\section{From Other SUS University}

$\%$ Graduated

$\%$ Still Enrolled
$4 \%$
$2 \%$
$4 \%$

$2 \%$
$5 \%$

$2 \%$
$4 \%$

$2 \%$
$4 \%$

$2 \%$

\section{From State University System}

$\begin{array}{lccccc}\text { \% Graduated } & 51 \% & 52 \% & 57 \% & 56 \% & 60 \% \\ \% \text { Still Enrolled } & 12 \% & 12 \% & 12 \% & 11 \% & 10 \% \\ \% \text { Success Rate } & 63 \% & 64 \% & 69 \% & 67 \% & 70 \%\end{array}$

Notes: First-time-in-college (FTIC) cohort is defined as undergraduates entering in fall term (or summer continuing to fall) with fewer than 12 hours earned since high school graduation. (1) Cohorts are based on undergraduate students who enter the institution in the Fall term (or Summer term and continue into the Fall term). Students of degree programs longer than four years (eg, PharmD) are included in the cohorts. The initial cohorts are revised to remove students, who have allowable exclusions as defined by IPEDS, from the cohort. (2) Success Rate measures the percentage of an initial cohort of students who have either graduated or are still enrolled. (3) Since degrees can be awarded after the last semester of coursework, the most recent year of data in this table provides preliminary graduation rate data that may change with the addition of "late degrees". Late degrees reported in conjunction with the IPEDS Graduation Rate Survey due in mid-April will be reflected in the following year. 
Section 4 - Undergraduate Education (continued)

TABLE 4E. AA Transfer Progression and Graduation Rates

\begin{tabular}{rccccc}
$\mathbf{2}$ - Year Rates & $\mathbf{2 0 0 6 - 0 8}$ & $\mathbf{2 0 0 7 - 0 9}$ & $\mathbf{2 0 0 8 - 1 0}$ & $\mathbf{2 0 0 9 - 1 1}$ & $\begin{array}{c}\mathbf{2 0 1 0 - 1 2} \\
\text { Preliminary }\end{array}$ \\
\hline Cohort & 2,009 & 2,216 & 2,536 & 2,333 & 2,484
\end{tabular}

From Same University

$\%$ Graduated

$\%$ Still Enrolled

$28 \%$

$59 \%$

$27 \% \quad 25 \%$

$61 \%$
$29 \%$
$60 \%$
$28 \%$

$60 \%$

From Other SUS University

$\begin{array}{lccccc}\% \text { Graduated } & 0 \% & 0 \% & 0 \% & 0 \% & 0 \% \\ \% \text { Still Enrolled } & 2 \% & 1 \% & 1 \% & 1 \% & 1 \%\end{array}$

From State University System

$\begin{array}{lccccc}\text { \% Graduated } & 28 \% & 27 \% & 26 \% & 29 \% & 28 \% \\ \% \text { Still Enrolled } & 60 \% & 61 \% & 62 \% & 61 \% & 61 \% \\ \% \text { Success Rate } & 88 \% & 88 \% & 88 \% & 90 \% & 89 \%\end{array}$

\section{4 - Year Rates}

Cohort

2004-08

2005-09

2006-10

2007-11

2008-12

From Same University

$\%$ Graduated
$\%$ Still Enrolled

$65 \%$

$11 \%$
$63 \%$

$13 \%$
$64 \%$

$12 \%$
$64 \%$

$12 \%$
$66 \%$

$11 \%$

\section{From Other SUS University}

$\begin{array}{lccccc}\% \text { Graduated } & 1 \% & 1 \% & 1 \% & 1 \% & 1 \% \\ \% \text { Still Enrolled } & 1 \% & 1 \% & 1 \% & 1 \% & 1 \%\end{array}$

\section{From State University System}

$\begin{array}{lccccc}\text { \% Graduated } & 66 \% & 64 \% & 65 \% & 66 \% & 67 \% \\ \% \text { Still Enrolled } & 12 \% & 13 \% & 13 \% & 13 \% & 12 \% \\ \% \text { Success Rate } & 78 \% & 78 \% & 79 \% & 79 \% & 79 \%\end{array}$

Notes: AA Transfer cohort is defined as undergraduates entering in the fall term (or summer continuing to fall) and having earned an AA degree from an institution in the Florida College System. (1) Cohorts are based on undergraduate students who enter the institution in the Fall term (or Summer term and continue into the Fall term); (2) Success Rate measures the percentage of an initial cohort of students who have either graduated or are still enrolled; (3) since degrees can be awarded after the last semester of coursework, the most recent year of data in this table provides preliminary graduation rate data that may change with the addition of "late degrees". Late degrees reported in conjunction with the IPEDS Graduation Rate Survey due in mid-April will be reflected in the following year. 


\section{Section 4 - Undergraduate Education (continued)}

TABLE 4F. Other Transfer Progression and Graduation Rates

\begin{tabular}{cccccc}
$\mathbf{5}$ - Year Rates & $\mathbf{2 0 0 3 - 0 8}$ & $\mathbf{2 0 0 4 - 0 9}$ & $\mathbf{2 0 0 5 - 1 0}$ & $\mathbf{2 0 0 6 - 1 1}$ & $\begin{array}{c}\mathbf{2 0 0 7 - 1 2} \\
\text { Preliminary }\end{array}$ \\
\hline Cohort Size & 2,399 & 2,495 & 2,498 & 2,592 & 2,842
\end{tabular}

\section{From Same University}

$\begin{array}{lccccc}\% \text { Graduated } & 56 \% & 56 \% & 54 \% & 60 \% & 60 \% \\ \% \text { Still Enrolled } & 7 \% & 7 \% & 7 \% & 7 \% & 6 \%\end{array}$

\section{From Other SUS University}

$\%$ Graduated

\% Still Enrolled

$2 \% \quad 2 \%$

$1 \%$

$$
2 \%
$$

$1 \%$

$2 \%$

$1 \%$
$2 \%$

$1 \%$

\section{From State University System}

$$
\begin{aligned}
& \text { \% Graduated } \\
& \% \text { Still Enrolled } \\
& \% \text { Success Rate }
\end{aligned}
$$

$58 \%$

$8 \%$

$65 \%$
$57 \%$

$8 \%$

$65 \%$
$55 \%$

$7 \%$

$62 \%$
$62 \%$

$61 \%$

$8 \%$

$7 \%$

$70 \%$

$68 \%$

Notes: (1) Cohorts are based on undergraduate students who enter the institution in the Fall term (or Summer term and continue into the Fall term); (2) Success Rate measures the percentage of an initial cohort of students who have either graduated or are still enrolled; (3) since degrees can be awarded after the last semester of coursework, the most recent year of data in this table provides preliminary graduation rate data that may change with the addition of "late degrees". Late degrees reported in conjunction with the IPEDS Graduation Rate Survey due in mid-April will be reflected in the following year. 
Section 4 - Undergraduate Education (continued)

TABLE 4G. Baccalaureate Degrees Awarded

2007-08

TOTAL

7184

2008-09

2009-10

2010-11

2011-12

9037

Notes: This is a count of baccalaureate degrees granted. Students who earn two distinct degrees in the same term are counted twice - whether their degrees are from the same six-digit CIP code or different CIP codes. Students who earn only one degree are counted once - even if they completed multiple majors or tracks.

\section{TABLE 4H. Baccalaureate Degrees Awarded in Areas of Strategic Emphasis}

2007-08 2008-09 2009-10 2010-11 2011-12

\begin{tabular}{|c|c|c|c|c|c|}
\hline $\begin{array}{l}\text { Science, Technology, } \\
\text { Engineering, and Math }\end{array}$ & 1,299 & 1,395 & 1,535 & 1,635 & 1,897 \\
\hline $\begin{array}{l}\text { Health Professions } \\
\text { *only disciplines in critical need }\end{array}$ & 420 & 435 & 439 & 439 & 683 \\
\hline $\begin{array}{l}\text { Security and Emergency } \\
\text { Services }\end{array}$ & 395 & 412 & 458 & 475 & 478 \\
\hline Globalization & 445 & 470 & 490 & 526 & 594 \\
\hline $\begin{array}{l}\text { Education } \\
\text { *only disciplines in critical need }\end{array}$ & 105 & 111 & 105 & 170 & 188 \\
\hline SUBTOTAL & 2,664 & 2,823 & 3,027 & 3,245 & 3,840 \\
\hline $\begin{array}{l}\text { Percent of ALL } \\
\text { Baccalaureate Degrees }\end{array}$ & $37 \%$ & $37 \%$ & $38 \%$ & $39 \%$ & $42 \%$ \\
\hline
\end{tabular}

Notes: This is a count of baccalaureate majors for specific Areas of Strategic Emphasis, as determined by the Board of Governors staff with consultation with business and industry groups and input from universities. A student who has multiple majors in the subset of targeted Classification of Instruction Program codes will be counted twice (i.e., double-majors are included). * This data represents select disciplines within these five areas and does not reflect all degrees awarded within the general field (of education or health). 


\section{Section 4 - Undergraduate Education (continued)}

TABLE 4I. Baccalaureate Degrees Awarded to Underrepresented Groups

\section{$2007-08 \quad 2008-09 \quad 2009-10 \quad 2010-11 \quad 2011-12$}

\section{Non-Hispanic Black}

$\begin{array}{cccccc}\text { Number of Degrees } & 821 & 906 & 883 & 935 & 942 \\ \text { Percentage of Degrees } & 12 \% & 12 \% & 11 \% & 12 \% & 11 \%\end{array}$

\section{Hispanic}

\begin{tabular}{cccccc} 
Number of Degrees & 782 & 884 & 966 & 1,166 & 1,437 \\
Percentage of Degrees & $11 \%$ & $12 \%$ & $12 \%$ & $14 \%$ & $17 \%$ \\
\hline -Grant Recipients & & & & & \\
\hline Number of Degrees & 2,707 & 2,885 & 3,260 & 3,763 & 4,476 \\
Percentage of Degrees & $39 \%$ & $39 \%$ & $41 \%$ & $46 \%$ & $50 \%$
\end{tabular}

Note: Non-Hispanic Black and Hispanic do not include students classified as Non-Resident Alien or students with a missing race code. Students who earn two distinct degrees in the same term are counted twice - whether their degrees are from the same six-digit CIP code or different CIP codes. Students who earn only one degree are counted once - even if they completed multiple majors or tracks. Percentage of Degrees is based on the number of baccalaureate degrees awarded to non-Hispanic Black and Hispanic students divided by the total degrees awarded - excluding those awarded to nonresident aliens and unreported. Pell-Grant recipients are defined as those students who have received a Pell grant from any SUS Institution within six years of graduation - excluding those awarded to non-resident aliens, who are only eligible for Pell grants in special circumstances. Percentage of Degrees is based on the number of baccalaureate degrees awarded to Pell recipients, as shown above, divided by the total degrees awarded - excluding those awarded to non-resident aliens. The number of degrees awarded to Pell recipients in 2010-11 is significantly higher in this year's report than last year's report due to a timing issue of when financial aid data is updated. 


\section{Section 4 - Undergraduate Education (continued)}

\section{TABLE 4J. Baccalaureate Degrees Without Excess Credit Hours}

\begin{tabular}{|c|c|c|c|c|c|}
\hline & 2007-08 & 2008-09 & 2009-10 & 2010-11 & 2011-12 \\
\hline FTIC & $44 \%$ & $43 \%$ & $47 \%$ & $50 \%$ & $57 \%$ \\
\hline AA Transfers & $58 \%$ & $61 \%$ & $58 \%$ & $60 \%$ & $60 \%$ \\
\hline Other Transfers & $46 \%$ & $49 \%$ & $49 \%$ & $49 \%$ & $40 \%$ \\
\hline TOTAL & $49 \%$ & $51 \%$ & $51 \%$ & $53 \%$ & $53 \%$ \\
\hline \multicolumn{6}{|c|}{$\begin{array}{l}\text { Notes: This table is based on statute } 1009.286 \text { (see link), and excludes certain types of student credits (ie, accelerated mechanisms, remedial coursework, } \\
\text { non-native credit hours that are not used toward the degree, non-native credit hours from failed, incomplete, withdrawn, or repeated courses, credit hours } \\
\text { from internship programs, credit hours up to } 10 \text { foreign language credit hours for transfer students in Florida, and credit hours earned in military science } \\
\text { courses that are part of the Reserve Officers' Training Corps (ROTC) program). This metric is not the same as the Excess Hours Surcharge, which has } \\
\text { multiple cohorts with varying fee rates. This table reports the percentage of baccalaureate degrees awarded within } 110 \% \text { of the catalog hours required for a } \\
\text { degree based on the Board of Governors Academic Program Inventory. This calculation is based on Hours To Degree data submitted by universities to the } \\
\text { Board of Governors and excludes recent graduates who have already earned a baccalaureate degree. }\end{array}$} \\
\hline
\end{tabular}

\section{TABLE 4K. Undergraduate Course Offerings}

Fall 2007 Fall 2008 Fall 2009 Fall $2010 \quad$ Fall 2011

$\begin{array}{cccccc}\begin{array}{c}\text { Number of } \\ \text { Course Sections }\end{array} & 3,275 & 3,023 & 3,157 & 3,261 & 3,333\end{array}$

\section{Percentage of Undergraduate Course Sections by Class Size}

\begin{tabular}{lccccc}
\hline Fewer than 30 Students & $61 \%$ & $57 \%$ & $59 \%$ & $58 \%$ & $61 \%$ \\
\hline 30 to 49 Students & $27 \%$ & $28 \%$ & $28 \%$ & $28 \%$ & $26 \%$ \\
\hline 50 to 99 Students & $10 \%$ & $12 \%$ & $11 \%$ & $11 \%$ & $10 \%$ \\
\hline 100 or More Students & $3 \%$ & $3 \%$ & $3 \%$ & $3 \%$ & $3 \%$
\end{tabular}

Notes: This data is based on Common Data Set (CDS) definitions. According to CDS, a "class section is an organized course offered for credit, identified by discipline and number, meeting at a stated time or times in a classroom or similar setting, and not a subsection such as a laboratory or discussion session. Undergraduate class sections are defined as any sections in which at least one degree-seeking undergraduate student is enrolled for credit. Exclude distance learning classes and noncredit classes and individual instruction such as dissertation or thesis research, music instruction, or one-to-one readings. Exclude students in independent study, co-operative programs, internships, foreign language taped tutor sessions, practicums, and all students in one-on-one classes. 


\section{Section 4 - Undergraduate Education (continued)}

\section{TABLE 4L. Percentage of Undergraduate Credit Hours Taught by}

\begin{tabular}{lccccc} 
& $\mathbf{2 0 0 7 - 0 8}$ & $\mathbf{2 0 0 8 - 0 9}$ & $\mathbf{2 0 0 9 - 1 0}$ & $\mathbf{2 0 1 0 - 1 1}$ & $\mathbf{2 0 1 1 - 1 2}$ \\
\hline Faculty & $61 \%$ & $63 \%$ & $65 \%$ & $66 \%$ & $68 \%$ \\
\hline Adjunct Faculty & $24 \%$ & $23 \%$ & $21 \%$ & $19 \%$ & $17 \%$ \\
\hline Graduate Students & $14 \%$ & $14 \%$ & $13 \%$ & $14 \%$ & $15 \%$ \\
\hline Other Instructors & $0 \%$ & $0 \%$ & $1 \%$ & $1 \%$ & $1 \%$ \\
\hline
\end{tabular}

Note: The total number of undergraduate state fundable credit hours taught will be divided by the undergraduate credit hours taught by each instructor type to create a distribution of the percentage taught by each instructor type. Four instructor types are defined as faculty (pay plans 01, 02, and 22), OPS faculty (pay plan 06), graduate student instructors (pay plan 05), and others (all other pay plans). If a course has more than one instructor, then the university's reported allocation of section effort will determine the allocation of the course's total credit hours to each instructor. The definition of faculty varies for Tables 4L, 4M and 4N. For Faculty Teaching Undergraduates, the definition of faculty is based on pay plans 01, 02, and 22.

\section{TABLE 4M. Undergraduate Instructional Faculty Compensation}

$2007-08 \quad 2008-09 \quad 2009-10 \quad 2010-11 \quad 2011-12$

\begin{tabular}{|c|c|c|c|c|c|}
\hline $\begin{array}{l}\text { Average Salary and Benefits } \\
\text { for Faculty Who Teach at Least } \\
\text { One Underaraduate Course }\end{array}$ & $\$ 93,079$ & $\$ 89,791$ & $\$ 93,039$ & $\$ 90,120$ & $\$ 91,083$ \\
\hline
\end{tabular}

Note: Average salary and benefits for all instructors of undergraduate courses who are on pay plan 22 . This amount is based on fall term data only, and to make it more meaningful to the reader we annualize (to a fall + spring amount) the fall-term salary and benefits. It is limited to faculty who taught at least one undergraduate course in the fall term and is reported as employed for at least 0.1 person year in the fall term. The definition of faculty varies for Tables 4L, 4M and 4N. For Undergraduate Instructional Faculty Compensation, the definition of faculty is based on pay plan 22.

\section{TABLE 4N. Student/Faculty Ratio}

\section{Fall 2007 Fall $2008 \quad$ Fall $2009 \quad$ Fall $2010 \quad$ Fall 2011}

$\begin{array}{llllll}\text { Ratio } & 26.8 & 27.1 & 27.3 & 24.0 & 26.1\end{array}$

Note: This data is based on Common Data Set (CDS) definitions. This is the Fall ratio of full-time equivalent students (full-time plus $1 / 3$ part time) to fulltime equivalent instructional faculty (full time plus $1 / 3$ part time). In the ratio calculations, exclude both faculty and students in stand-alone graduate or professional programs such as medicine, law, veterinary, dentistry, social work, business, or public health in which faculty teach virtually only graduatelevel students. Do not count undergraduate or graduate student teaching assistants as faculty. 


\section{Section 4 - Undergraduate Education (continued)}

\section{TABLE 40. Professional Licensure/Certification Exams}

\begin{tabular}{lccccc} 
Nursing: National Council Licensure Examination for Registered Nurses & \\
& $\mathbf{2 0 0 7 - 0 8}$ & $\mathbf{2 0 0 8 - 0 9}$ & $\mathbf{2 0 0 9 - 1 0}$ & $\mathbf{2 0 1 0 - 1 1}$ & $\mathbf{2 0 1 1 - 1 2}$ \\
\hline Examinees & 152 & 157 & 151 & 169 & 210 \\
Pass Rate & $92 \%$ & $98 \%$ & $96 \%$ & $96 \%$ & $95 \%$ \\
National Benchmark & $86 \%$ & $88 \%$ & $90 \%$ & $89 \%$ & $89 \%$
\end{tabular}

Note: Pass rate for first-time examinees for the National Council Licensure Examination for Registered Nurses (NCLEX-RN) are based on the performance of graduates of baccalaureate nursing programs. National benchmark data is based on Jan-Dec NCLEX-RN results for first-time examinees from students in US-educated baccalaureate degree programs as published by the National Council of State Boards of Nursing.

\section{TABLE 4P. Tuition Differential Fee (TDF)}

\begin{tabular}{lccc} 
& $\mathbf{2 0 1 0 - 1 1}$ & $\mathbf{2 0 1 1 - 1 2}$ & $\begin{array}{c}\mathbf{2 0 1 2 - 1 3} \\
\text { Projected }\end{array}$ \\
\hline TDF Revenues Generated & $\$ 14,376,755$ & $\$ 22,361,250$ & $\$ 35,359,828$ \\
\hline Students Receiving TDF Funded Award & 3,346 & 5,235 & $\mathrm{n} / \mathrm{a}$ \\
\hline Value of TDF Funded Award & $\$ 1,289$ & $\$ 1,282$ & $\mathrm{n} / \mathrm{a}$
\end{tabular}

\section{Florida Student Assistance Grant (FSAG) Eligible Students}

\begin{tabular}{lccc}
\hline Number of Eligible Students & 7,856 & 8,147 & $\mathrm{n} / \mathrm{a}$ \\
\hline Number Receiving a TDF Waiver & 0 & 0 & $\mathrm{n} / \mathrm{a}$ \\
\hline Value of TDF Waivers & $\$ 0$ & $\$ 0$ & $\mathrm{n} / \mathrm{a}$
\end{tabular}

Note: TDF Revenues Generated refers to actual tuition differential revenues collected from undergraduate students as reported on the Operating Budget, Report 625 - Schedule I-A. Students Receiving TDF Funded Award reports the number of unduplicated students who have received a financial aid award that was funded by tuition differential revenues. Value of TDF Funded Award refers to the average value of financial aid awards funded by the the Tuition Differential Fee funds. Florida Student Assistance Grant (FSAG) Eligible Students: Number of Eligible Students refers to total annual unduplicated count of undergraduates at the institution who are eligible for FSAG in the academic year, whether or not they received FSAG awards. Number Receiving a TDF Waiver refers to annual unduplicated count of FSAG-eligible students receiving a waiver, partial or full, of the tuition differential fees at the institution during the academic year, regardless of the reason for the waiver. Value of TDF Waivers refers to the average value of waivers provided to FSAG-eligible undergraduates at the institution during the academic year, regardless of the reason for the waiver. 


\section{Section 5 - Graduate Education}

\section{TABLE 5A. Graduate Degree Program Changes in AY 2011-12}

\begin{tabular}{|c|c|c|c|c|c|c|}
\hline Title of Program & $\begin{array}{l}\text { Six-digit } \\
\text { CIP } \\
\text { Code }\end{array}$ & $\begin{array}{c}\text { Degree } \\
\text { Level }\end{array}$ & $\begin{array}{l}\text { Date of } \\
\text { UBOT } \\
\text { Action }\end{array}$ & $\begin{array}{l}\text { Starting } \\
\text { or Ending } \\
\text { Term }\end{array}$ & $\begin{array}{l}\text { Date of } \\
\text { Board of } \\
\text { Governors } \\
\text { Action }\end{array}$ & Comments \\
\hline \multicolumn{7}{|l|}{ New Programs } \\
\hline Secondary English Education & 13.1305 & Master & Dec. 11,2012 & Fall 2012 & & $\begin{array}{l}\text { Sarasota- } \\
\text { Manatee }\end{array}$ \\
\hline $\begin{array}{l}\text { Middle Grades Science, } \\
\text { Technology, Engineering, and } \\
\text { Mathematics Education }\end{array}$ & 13.1203 & Master & Dec. 11,2012 & Fall 2012 & & $\begin{array}{c}\text { St. } \\
\text { Petersburg }\end{array}$ \\
\hline Exercise Science & 31.0505 & Master & Oct. 11,2012 & Spring 2012 & & Tampa \\
\hline Health Informatics & 51.2706 & Master & Dec. 11,2012 & Spring 2012 & & Tampa \\
\hline Environmental Engineering & 14.1401 & $\begin{array}{l}\text { Research } \\
\text { Doctorate }\end{array}$ & & Spring 2012 & Jan., 2012 & Tampa \\
\hline \multicolumn{7}{|l|}{ Terminated Programs } \\
\hline Art Teacher Ed & 13.1302 & Master & Jun. 11,2012 & $\begin{array}{c}\text { Summer } \\
2011\end{array}$ & & Tampa \\
\hline Higher Ed Administration & 13.0406 & Master & Jun. 11,2012 & $\begin{array}{l}\text { Spring } \\
2006\end{array}$ & & Tampa \\
\hline Dramatic Writing & 50.0504 & Master & Jun. 11,2012 & $\begin{array}{c}\text { Summer } \\
2011\end{array}$ & & Tampa \\
\hline \multicolumn{7}{|l|}{ Inactive Programs } \\
\hline None & & & & & & \\
\hline
\end{tabular}

None

Note: This table does not include new majors or concentrations added under an existing degree program CIP Code. This table reports the program changes between May 5, 2011 and May 4, 2012. New Programs are proposed new degree programs that have been completely through the approval process at the university and, if appropriate, the Board of Governors. Does not include new majors or concentrations added under an existing degree program CIP Code. Terminated Programs are degree programs for which the entire CIP Code has been terminated and removed from the university's inventory of degree programs. Does not include majors or concentrations terminated under an existing degree program CIP Code if the code is to remain active on the academic degree inventory. Inactive Programs are degree programs for which enrollments have been temporarily suspended for the entire CIP Code, but the program CIP Code has not been terminated. Does not include majors or concentrations suspended under an existing degree program CIP Code if the code is to remain active on the academic degree inventory and new enrollments in any active major will be reported. New Programs Considered by University But Not Approved includes any programs considered by the university board of trustees, or any committee of the board, but not approved for implementation. Also include any programs that were returned prior to board consideration by the university administration for additional development, significant revisions, or re-conceptualization; regardless of whether the proposal was eventually taken to the university board for approval. Count the returns once per program, not multiple times the proposal was returned for revisions, unless there is a total re-conceptualization that brings forward a substantially different program in a different CIP Code. 
Section 5 - Graduate Education (continued)

TABLE 5B. Graduate Degrees Awarded

\begin{tabular}{lccccc} 
& $\mathbf{2 0 0 7 - 0 8}$ & $\mathbf{2 0 0 8 - 0 9}$ & $\mathbf{2 0 0 9 - 1 0}$ & $\mathbf{2 0 1 0 - 1 1}$ & $\mathbf{2 0 1 1 - 1 2}$ \\
\hline \multicolumn{1}{c}{ TOTAL } & $\mathbf{2 , 6 8 5}$ & $\mathbf{2 , 8 8 4}$ & $\mathbf{2 , 9 4 4}$ & $\mathbf{3 , 0 1 0}$ & $\mathbf{3 , 1 5 9}$ \\
\hline Masters and Specialist & 2,313 & 2,482 & 2,544 & 2,585 & 2,742 \\
\hline Research Doctoral & 229 & 248 & 244 & 269 & 271 \\
\hline Professional Doctoral & 143 & 154 & 156 & 156 & 146 \\
\hline a) Medicine & 115 & 114 & 116 & 109 & 112 \\
b) Law & 0 & 0 & 0 & 0 & 0 \\
c) Pharmacy & 0 & 0 & 0 & 0 & 0
\end{tabular}

Note: The total number of Professional Doctoral degrees includes other programs that are not specifically identified in lines $a, b$, and $c$.

TABLE 5C. Graduate Degrees Awarded in Areas of Strategic Emphasis

2007-08 2008-09 2009-10 2010-11 2011-12

\begin{tabular}{lccccc}
\hline $\begin{array}{l}\text { Science, Technology, } \\
\text { Engineering, and Math }\end{array}$ & 552 & 530 & 616 & 658 & 730 \\
\hline $\begin{array}{l}\text { Health Professions } \\
\text { *only disciplines in critical need }\end{array}$ & 429 & 506 & 566 & 662 & 650 \\
\hline $\begin{array}{l}\text { Security and Emergency } \\
\text { Services }\end{array}$ & 36 & 53 & 40 & 31 & 45 \\
\hline $\begin{array}{l}\text { Globalization } \\
\text { Education }\end{array}$ & 46 & 41 & 54 & 49 & 67 \\
\hline $\begin{array}{l}\text { *only disciplines in critical need } \\
\text { SUBTOTAL }\end{array}$ & 200 & 234 & 188 & 170 & 168 \\
\hline $\begin{array}{l}\text { Percent of All } \\
\text { Graduate Degrees }\end{array}$ & $\mathbf{1 , 2 6 3}$ & $\mathbf{1 , 3 6 4}$ & $\mathbf{1 , 4 6 4}$ & $\mathbf{1 , 5 7 0}$ & $\mathbf{1 , 6 6 0}$ \\
\hline
\end{tabular}

Notes: This is a count of baccalaureate majors for specific Areas of Strategic Emphasis, as determined by the Board of Governors staff with consultation with business and industry groups and input from universities. A student who has multiple majors in the subset of targeted Classification of Instruction Program codes will be counted twice (i.e., double-majors are included). ${ }^{*}$ This data represents select disciplines within these five areas and does not reflect all degrees awarded within the general field (of education or health). 


\section{Section 5 - Graduate Education (continued)}

TABLE 5D. Professional Licensure Exams for Graduate Programs

Medicine: US Medical Licensing Exam (Step 1)

\begin{tabular}{lccccc} 
& $\mathbf{2 0 0 8}$ & $\mathbf{2 0 0 9}$ & $\mathbf{2 0 1 0}$ & $\mathbf{2 0 1 1}$ & $\mathbf{2 0 1 2}^{*}$ \\
\hline Examinees & 117 & 117 & 116 & 110 & 125 \\
Pass Rate & $97 \%$ & $97 \%$ & $97 \%$ & $99 \%$ & $91 \%$ \\
National Benchmark & $93 \%$ & $93 \%$ & $91 \%$ & $94 \%$ & $96 \%$
\end{tabular}

*Data is preliminary

Medicine: US Medical Licensing Exam (Step 2) Clinical Knowledge

\begin{tabular}{lccccc} 
& $\mathbf{2 0 0 7 - 0 8}$ & $\mathbf{2 0 0 8 - 0 9}$ & $\mathbf{2 0 0 9 - 1 0}$ & $\mathbf{2 0 1 0 - 1 1}$ & $\mathbf{2 0 1 1 - 1 2}$ \\
\hline Examinees & 101 & 121 & 128 & 122 & 115 \\
Pass Rate & $100 \%$ & $100 \%$ & $100 \%$ & $99 \%$ & $99 \%$ \\
National Benchmark & $96 \%$ & $96 \%$ & $97 \%$ & $97 \%$ & $98 \%$
\end{tabular}

Medicine: US Medical Licensing Exam (Step 2) Clinical Skills

\begin{tabular}{lccccc} 
& $\mathbf{2 0 0 7 - 0 8}$ & $\mathbf{2 0 0 8 - 0 9}$ & $\mathbf{2 0 0 9 - 1 0}$ & $\mathbf{2 0 1 0 - 1 1}$ & $\mathbf{2 0 1 1 - 1 2}$ \\
\hline Examinees & 92 & 118 & 116 & 122 & 100 \\
Pass Rate & $97 \%$ & $97 \%$ & $96 \%$ & $100 \%$ & $98 \%$ \\
National Benchmark & $97 \%$ & $97 \%$ & $97 \%$ & $98 \%$ & $97 \%$
\end{tabular}

Physical Therapy: National Physical Therapy Examinations

\begin{tabular}{lccccc} 
& $\mathbf{2 0 0 5 - 0 7}^{*}$ & $\mathbf{2 0 0 6 - 0 8 *}^{*}$ & $\mathbf{2 0 0 7 - 0 9 *}^{*}$ & $\mathbf{2 0 0 8 - 1 0}$ & $\mathbf{2 0 0 9 - 1 1}$ \\
\hline Examinees & 51 & 43 & 51 & 81 & 96 \\
Pass Rate & $82 \%$ & $88 \%$ & $86 \%$ & $85 \%$ & $87 \%$ \\
National Benchmark & $86 \%$ & $86 \%$ & $87 \%$ & $87 \%$ & $89 \%$
\end{tabular}

*No USF Graduates in 2007

Note: We have chosen to compute a three-year average pass rate for first-time examinees on the National Physical Therapy Examinations by exam year, rather than report the annual averages, because of the relatively small cohort sizes compared to other licensed professional programs. 


\section{Section 6 - Research and Economic Development TABLE 6A. Research and Development}

\section{$2006-07 \quad 2007-08 \quad 2008-09 \quad 2009-10 \quad 2010-11$}

R\&D Expenditures

Total

(\$1,000s)

Federally Funded

(\$1,000s)

Percent Funded

From External Sources

Total R\&D Expenditures

Per Full-Time, Tenured,

Tenure-Earning Faculty

Member (\$)
$\$ 337,169 \quad \$ 342,665 \quad \$ 371,037 \quad \$ 390,828 \quad \$ 400,679$

$\$ 171,272 \quad \$ 189,282 \quad \$ 213,163 \quad \$ 246,016 \quad \$ 245,410$

$\begin{array}{lllll}76.5 \% & 79.5 \% & 80.3 \% & 78.5 \% & 77.3 \%\end{array}$

\section{Technology Transfer}

Invention Disclosures

U.S. Patents Issued

Patents Issued Per 1,000

Full-Time, Tenured and

Tenure-Earning Faculty
110

139

141

161

172

31

31

36

66

91

26

26

28

52

80
Licenses/ Options Executed

Licensing Income

Received (\$)
Number of Start-Up

Companies
23

28

25

37

36

$\$ 1,300,000$

3

Note: R\&D Expenditures are based on the National Science Foundation's annual Survey of R\&D Expenditures at Universities and Colleges (data include Science \& Engineering and non-Science \& Engineering awards). Percent Funded from External Sources is defined as funds from federal, private industry and other sources (non-state and non-institutional funds). Total R\&D expenditures are divided by fall, full-time tenured/tenure-track faculty as reported to IPEDS (FGCU includes both tenured/tenure-track and non-tenure/track faculty). The fall faculty year used will align with the beginning of the fiscal year, so that (e.g.) 2007 FY R\&D expenditures are divided by fall 2006 faculty. Technology Transfer data are based on the Association of University Technology Managers Annual Licensing Survey. Licensing Income Received refers to license issue fees, payments under options, annual minimums, running royalties, termination payments, amount of equity received when cashed-in, and software and biological material end-user license fees of $\$ 1,000$ or more, but not research funding, patent expense reimbursement, valuation of equity not cashed-in, software and biological material end-user license fees of less than $\$ 1,000$, or trademark licensing royalties from university insignia. Number of Start-up Companies that were dependent upon the licensing of University technology for initiation. 


\section{Section 6 - Research and Economic Development (continued)}

\section{TABLE 6B. Centers of Excellence}

\begin{tabular}{|c|l|}
\hline Name of Center: & Center for Drug Discovery and Innovation (CDDI) \\
\hline Year Created: & FY 2007 \\
\hline
\end{tabular}

\section{Cumulative}

(since inception

to June 2012)
Fiscal Year

2011-12

\section{Research Effectiveness}

Only includes data for activities directly associated with the Center. Does not include the non-Center activities for faculty who are associated with the Center.

Number of Competitive Grants Applied For

Value of Competitive Grants Applied For (\$)

Number of Competitive Grants Received

Value of Competitive Grants Received (\$)

Total Research Expenditures (\$)

Number of Publications in Refereed Journals

From Center Research

Number of Invention Disclosures

Number of Licenses/Options Executed

Licensing Income Received (\$)

\section{Collaboration Effectiveness}

Only reports on relationships that include financial or in-kind support.

Collaborations with Other Postsecondary Institutions

Collaborations with Private Industry

Collaborations with K-12 Education Systems/Schools

Undergraduate and Graduate Students Supported

with Center Funds

\begin{tabular}{|c|c|}
\hline 133 & 37 \\
\hline$\$ 74,169,154$ & $\$ 12,222,037$ \\
\hline 43 & 25 \\
\hline$\$ 17,269,173$ & $\$ 8,829,626$ \\
\hline$\$ 15,454,783$ & $\$ 3,207,618$ \\
\hline 147 & 28 \\
\hline 28 & 2 \\
\hline 2 & 0 \\
\hline$\$ 163,071$ & $\$ 0$ \\
\hline
\end{tabular}

\section{Economic Development Effectiveness}

Number of Start-Up companies

with a physical presence, or employees, in Florida

Jobs Created By Start-Up Companies

Associated with the Center

Specialized Industry Training and Education

Private-sector Resources Used to Support

the Center's Operations 


\section{Section 6 - Research and Economic Development (continued) TABLE 6B. Centers of Excellence (continued)}

Name of Center

Narrative Comments [Most Recent Year]:
Center for Drug Discovery and Innovation (CDDI)

(1) In March of 2012, the build-out of the Chemdiversity lab was completed by Whiting Turner and the keys officially handed over to the Center for Drug Discovery and Innovation. (2) During the fiscal year 2011/12, the planned phase-out of the Biotechnology Development and Testing Facility (BDT) began with the inception of the Protein Production Lab. The addition of the two new core facilities was necessary to ensure that the services being offered to the wider community were aligned with the overall mission of early drug discovery. (3) In January 2012, Dr. Jeremiah Tipton was appointed the new manager of the Proteomics Lab. (4) In May 2012, Dr. Jinyi Zhu, through a joint appointment with Molecular Medicine and the Center for Drug Discovery and Innovation, was appointed the manager for the Center's Protein Production Lab.

(5) The Center for Drug Discovery and Innovation, along with the Global Health Infectious Disease Program, hosted a one-day symposium on April 6, 2012, at the Patel Center for Global Solutions. The event drew the participation of a number of national experts in infectious disease drug discovery. 


\section{Section 6 - Research and Economic Development (continued)} TABLE 6C. State University Research Commercialization Assistance Grants

\begin{tabular}{|c|c|c|c|}
\hline \multirow{2}{*}{ Project Name by Type of Grant } & \multirow{2}{*}{$\begin{array}{l}\text { Year } \\
\text { Grant } \\
\text { Awarded }\end{array}$} & \multicolumn{2}{|c|}{ Cumulative } \\
\hline & & Awards & Expenditures \\
\hline \multicolumn{4}{|l|}{ Phase I Grants } \\
\hline & & & \\
\hline \multicolumn{4}{|l|}{ Phase II Grants } \\
\hline & & & \\
\hline & & & \\
\hline \multicolumn{4}{|l|}{ Phase III Grants } \\
\hline MDI Partners, LLC & & & \\
\hline & & & \\
\hline Natura Therapeutics, Inc. & & $\$ 65,000$ & $\$ 58,5$ \\
\hline Total for all SURCAG Grants & & $\$ 400,000$ & $\$ 333,221$ \\
\hline \multicolumn{4}{|c|}{$\begin{array}{l}\text { Narrative Comments: For each project, provide a brief update on (1) the project's progress } \\
\text { towards completing its key milestones/deliverables; and (2) the project's return on investment } \\
\text { for the university and state. }\end{array}$} \\
\hline \multicolumn{4}{|c|}{$\begin{array}{l}\text { Phase III Grants } \\
\text { MDI Partners: } \\
\text { The overall goal for this grant was to finalize the design of the speculum sheath, gear up for manufacturing, } \\
\text { submit an application for FDA approval, and ultimately get commercial product on the market. In support of this } \\
\text { goal and milestones proposed in the grant, MDI designed and built the beta prototypes. The initial user } \\
\text { preference clinical study was completed, and a follow-on effectiveness study was initiated in } 136 \text { patients. The } \\
510 \text { k submission is planned for December 2012, with market launch anticipated by December } 2013 \text {. }\end{array}$} \\
\hline \multicolumn{4}{|c|}{$\begin{array}{l}\text { Rehab Ideas: } \\
\text { The overall goal for this grant was to commercialize five innovative products designed specifically for individuals } \\
\text { with disabilities including the Mobili-T Rover, Backpack Retriever, TrayAway, Folding Crutch and Sideways } \\
\text { Wheelchair Kit. In further support of this goal and milestones proposed in the grant, Rehab Ideas improved the } \\
\text { Mobili-T Rover design, produced several units, and showcased the Rover at an international conference. } \\
\text { Marketing efforts continue to grow sales in Backpack Retriever, and TrayAway. A prototype Folding Crutch } \\
\text { was made, and tooling for manufacturing is pending. The Sideways Wheelchair Kit project was discontinued } \\
\text { due to potential stability issues. }\end{array}$} \\
\hline \multicolumn{4}{|c|}{$\begin{array}{l}\text { Natura Therapeutics: } \\
\text { Natura's overall goal for this grant was to develop and commercialize a combination product for supporting } \\
\text { cellular health and weight loss, NutraStem®Slim. In support of this goal and the milestones proposed in the } \\
\text { grant, Natura established a single dosage that was beneficial for stem cell health and for promoting weight loss. } \\
\text { A peer reviewed scientific manuscript is in progress. Finished product manufacturing is projected to begin June }\end{array}$} \\
\hline
\end{tabular}


2013 with a market launch later that year.

Section 6 - Research and Economic Development (continued) TABLE 6D. 21st Century World Class Scholars Program

\begin{tabular}{|c|c|c|c|c|c|}
\hline \multirow[b]{2}{*}{$\begin{array}{l}\text { World Class } \\
\text { Scholar(s) }\end{array}$} & \multirow[b]{2}{*}{$\begin{array}{l}\text { Scholar's } \\
\text { Field }\end{array}$} & \multirow{2}{*}{$\begin{array}{c}\text { Grant } \\
\text { Amount } \\
\text { Awarded } \\
\text { (Thousand \$) } \\
\text { State Dollars } \\
\text { Only }\end{array}$} & \multicolumn{3}{|c|}{$\begin{array}{l}\text { Report the cumulative activity } \\
\text { since each scholar's award. }\end{array}$} \\
\hline & & & $\begin{array}{l}\text { External } \\
\text { Research } \\
\text { Awards } \\
\text { (Thousand \$) }\end{array}$ & $\begin{array}{l}\text { Patent } \\
\text { Filed / } \\
\text { Issued }\end{array}$ & $\begin{array}{c}\text { Licensing } \\
\text { Revenues } \\
\text { Generated } \\
\text { (\$) }\end{array}$ \\
\hline John Adams & Global Health & $\$ 2,000$ & $\$ 10,970$ & 4 filed & $\$ 0$ \\
\hline Richard Gitlin & $\begin{array}{l}\text { Electrical } \\
\text { Engineering }\end{array}$ & $\$ 2,000$ & $\$ 336$ & 8 filed & $\$ 500$ \\
\hline James Mihelcic & $\begin{array}{l}\text { Environmental } \\
\text { Engineering }\end{array}$ & $\$ 2,000$ & $\$ 871$ & 0 & $\$ 0$ \\
\hline Thomas Unnasch & Global Health & $\$ 2,000$ & $\$ 8,009$ & 0 & $\$ 0$ \\
\hline TOTAL & & $\$ 8,000$ & $\$ 20,186$ & 12 filed & $\$ 500$ \\
\hline
\end{tabular}


Dr. John Adams, Professor of Global Health, came to USF in May 2007 from the University of Notre Dame's Center for Tropical Disease Research and Training, where he made important advances in malaria genetics and vaccine development. A devastating disease, malaria is a major economic drain in affected countries and leads to severe anemia and death in young children and pregnant women. Dr. Adams' laboratory studies protein ligands that help malaria parasites bind to a person's red blood cell wall, beginning a cascade of replication that leads to the massive destruction of oxygen-carrying red blood cells. He was issued U.S. patents for two of these proteins because of their potential use in a malaria vaccine. With the support of grants from the National Institutes of Health $(\mathrm{NIH})$, Dr. Adams is using advanced analytic technologies to pursue effective vaccine and mosquito-based therapies to prevent malaria caused by Plasmodium vivax and $P$. falciparum, the most common types of malaria. Dr. Adams oversees the Vector-Borne Pathogen Laboratory, or insectary, where researchers will study the complex life cycle of the malaria parasite transmitted by mosquitoes. Dr. Adams currently serves as Editor of Infection \& Immunity, and is active on the USF Graduate Council, as well as the Tenure \& Promotion Committees in his department and college. He currently sponsors 4 postdoctoral and 4 predoctoral scholars and has provided undergraduate research experiences for more than 50 students, including honors students. Dr. Adams has published more than 90 referred publications and actively collaborates with USF-affiliate Draper Laboratory.

Dr. Richard D. Gitlin, Agere Systems Chair Distinguished Professor of Electrical Engineering, has more than 40 years of leadership in the communications and networking industry, directing pioneering research and development in digital communications, broadband networking, and wireless systems. Since joining USF in 2008 , he has focused on the synergies between advanced communications technologies and bio-medical systems by investigating the potential for wireless networking of in vivo miniature wirelessly controlled devices to enable a paradigm shift in Minimally Invasive Surgery (MIS). This research has produced nine papers, four patent filings, and two NSF grants. The system patent for advancing MIS surgery has just been allowed and should become a dominant patent in this domain. Dr. Gitlin is involved with a USF start-up company, Innovatia Medical Systems, which was formed to support and commercialize the work of Dr. Gitlin's Miniature Anchored Remote Videoscope for Expedited Laparoscopy (MARVEL) research team comprised of engineering students. Dr. Gitlin has updated and taught the following graduate level courses at USF: EEL6534 Digital Communications, EEL6545 Random Processes, and EEL6597 Wireless Networking. Dr. Gitlin's USF service activities include: Member, USF Board of Trustees working group on Audit and Finance (2008-2011); Member, USF System Strategic Planning Committee (2010-2011); Chair, EE Department Personnel Committee (2009-2011); Chair, EE Department Academic Affairs Committee (2012-); and Executive Committee, USF Chapter of the National Academy of Inventors (2012-).

James R. Mihelcic is Professor of Civil and Environmental Engineering, where he directs the Peace Corps Master's International Program in Civil \& Environmental Engineering. Dr. Mihelcic is a member of the EPA Chartered Science Advisory Board and a Board Certified Environmental Engineering Member and Board Trustee of the American Academy of Environmental Engineers (AAEE). He is lead author for three textbooks: Fundamentals of Environmental Engineering (John Wiley \& Sons, 1999); Field Guide in Environmental Engineering for Development Workers: Water, Sanitation, Indoor Air (ASCE Press, 2009); and Environmental Engineering: Fundamentals, Sustainability, Design (John Wiley \& Sons, 2010). His areas of interest are sustainability, impact of anthropogenic stressors on water resources, water supply, and wastewater treatment, water, and sanitation in the developing world, engineering education. His research is currently supported by externally funded research from the National Science Foundation, U.S. Agency for International Development, WateReuse Foundation, and CARE Madagascar. Dr. Mihelcic teaches courses at USF in environmental engineering, sustainable development engineering, aquatic chemistry, and professionalism and ethics. He has conducted university service related to development of the master's degree in Global Sustainability and led efforts that created the Ph.D. Environmental Engineering degree. At the department level, he has led or served on committees for new faculty searches, engineering $\mathrm{ABET}$ accreditation, and faculty promotion and tenure. 
Dr. Thomas Unnasch is the Department Chair and Professor in the Department of Global Health. Dr. Unnasch directs the Global Health Infectious Diseases Research (GHIDR) program's Biosafety Level 3 (BSL-3) Laboratory, which primarily houses his team's work with Eastern equine encephalitis virus (EEEV). He is a leading authority on the ecology of EEEV and other encephalitis viruses such as the West Nile virus. His research has focused upon vector-borne diseases and the human filarial infections. The laboratory concentrates upon research areas that have a direct impact upon disease control and elimination programs targeting vector-borne pathogens worldwide. The laboratory has been instrumental in the development of molecular-based methods for the detection of the river blindness parasite Onchocerca volvulus both in humans and in its black-fly vector. He and his team are also working closely with collaborators in Africa and Latin America to develop spatial models to predict zones that are at risk for onchocerciasis using remote sensing data, and to develop more efficient methods for the collection of vector blackflies to monitor transmission of onchocerciasis. In the field of arboviral infections, the laboratory is studying the ecology of Eastern Equine Encephalitis virus (EEEV) in the Southeastern USA, concentrating on elucidating the dynamic processes in the host-vector relationship that are drivers in the development of EEEV enzootics and epidemics. This work has recently been featured in stories in the New York Times, Science Direct, and MSNBC. The ultimate goal of these studies is to develop a predictive model for habitats that are most likely to represent EEEV enzootic foci. Such a model could be used to target most efficiently the surveillance and vector control efforts of the mosquito control programs throughout Florida and the Southeastern USA. Dr. Unnasch has served as the co-Director for the Center of Biological Defense at USF and on numerous College-wide leadership committees, including the Dean's Research Advisory committee, the College Appointment, Promotion and Awards Committee, and various admission committees. Dr. Unnasch serves a leadership role in numerous national and international organizations, including the Board of Directors of the Florida Mosquito Control Association, the Mectizan Donation Committee and the Chair of Uganda's Expert Advisory Committee for Onchocerciasis Elimination. He serves on the editorial boards of several peer-reviewed journals and is the editor in chief of Research Reports in Tropical Medicine. Dr. Unnasch has supervised many MSPH and PhD students; is course director for PHC 6561 Laboratory Techniques in Public Health, PHC 6934 Tools of Research: Laboratory Rotations, PHC 7931 Advanced Interdisciplinary Seminar: Current Topics in Global Health Infectious Disease Research; and serves as a guest lecturer in numerous classes in the College of Public Health and School of Medicine. 